\title{
Be Nice to Your Innovators: Employee Treatment and Corporate Innovation Performance
}

\author{
Chen Chen $^{\mathrm{a}, *}$ \\ Yangyang Chen ${ }^{\mathrm{b}}$ \\ Po-Hsuan $\mathrm{Hsu}^{\mathrm{c}}$ \\ Edward J. Podolski ${ }^{\mathrm{d}}$
}

June 2016

a Department of Accounting, Monash University, Caulfield East, VIC 3145, Australia. Email: chen.chen2@monash.edu

b School of Accounting and Finance, The Hong Kong Polytechnic University, Hung Hom, Kowloon, Hong Kong. Email: yangchen@ @olyu.edu.hk

${ }^{c}$ Faculty of Business and Economics, The University of Hong Kong, Pokfulam Road, Hong Kong. Email: paulhsu@hku.hk

d Department of Finance, Deakin University, Burwood, VIC 3125, Australia. Email: edward.podolski@deakin.edu.au

* Corresponding author. Tel: +6139903 2023.

We would like to thank Henk Berkman, Christine Brown, Krishnamurthy Subramanian, Xin Chang, Rui Ge, Ning Gong, Ferdinand Gul, Yen-Teik Lee, Chien-Ting Lin, Jeffry Netter (the editor), Zigan Wang, Wei Opie, Hongfeng Zhang, Wenrui Zhang, Tong Zhou, Leon Zolotoy, and seminar participants at Deakin University for their valuable comments. We also thank Xin Chang and Wenrui Zhang for sharing with us the non-executive stock option data. Po-Hsuan Hsu acknowledges the General Research Fund (GRF) sponsored by the Research Grants Council in Hong Kong (790913). All errors are our own. 


\title{
Be Nice to Your Innovators: Employee Treatment and Corporate Innovation Performance
}

\begin{abstract}
This paper investigates the effect that employee treatment schemes have on corporate innovation performance. We find that firms with better employee treatment schemes produce more and better patents through improving employee satisfaction and teamwork. Additional tests suggest that our main findings cannot be attributed to job security, unionization, reverse causality, and omitted variables. We also find that firms with better employee treatment schemes produce patents that enhance market valuation and facilitate better future operating performance. Collectively, our findings show that treating employees well benefits firms and shareholders, for well treated employees are encouraged to create intellectual property.
\end{abstract}

JEL Classification: G32, M14, M51, O31.

Keywords: Employee satisfaction; Corporate innovation; Innovative strategies; Patents; Citations. 
Since instituting the "Employee First, Customer Second" strategy, staff have become more loyal. Innovation often is driven from this level of the company.

The Wall Street Journal (Feb 20, 2013)—“Unleashing Innovation: How to Keep Employees."

\section{Introduction}

Successful corporations efficiently convert resource inputs into new products or services, a process that requires continual innovation in order to develop and retain a competitive edge over ones' rivals. A key input in the innovative process is human capital, such as highly skilled researchers and engineers. For instance, Hall (2002) points out that over 50 percent of R\&D expenses are the salaries of these highly skilled employees. Investment in human capital, however, is not limited to salaries or even performance bonuses, but rather encompasses how the employers treat their employees. Employers can, for example, invite employees to participate in corporate decision making, provide employees with more flexible working schedules, offer them stronger health and safety programs, and event create more inclusive and diverse work environments. Anecdotal evidence from the high-tech industry suggests that treating employees well is a key factor of firms' innovative success. For example, Google's "20 percent time", a program that gives employees the freedom to spend 20 percent of their paid time as they please, gave birth to some of its more iconic products including Gmail and Google Earth. Even a few generations ago, 3M launched "15 percent program" in 1948 to allow employees to use a portion of their paid time to pursue their own innovative ideas, and this program yielded numerous successful products, including Post-It. In light of the important role that employees play in the innovative process, as well as the anecdotal evidence which highlights the usefulness of employee treatment schemes in motivating innovation, this paper formally examines the effect 
that employee treatment schemes have on corporate innovative success.

The idea that employee treatment schemes are relevant to firm performance is not new. Prior studies find that positive employee treatment schemes have a favorable impact on firms' operational, financial, and stock price performance (Jiao, 2010; Edmans, 2011; Faleye and Trahan, 2011; Ertugrul, 2013). For example, Edmans (2011) finds that the stock returns of firms that treat their employees more positively exceed the stock returns of firms that do not treat their employees as well. Similarly, Verwijmeren and Derwall (2010) and Bae et al. (2011) find that positive employee treatment schemes are negatively associated with the probability of default and debt ratios. Ghaly et al. (2015) show that employee treatment is positively correlated with cash holdings. More broadly, corporate social responsibility, of which employee treatment is considered a component, has been found to reduce the cost of capital (Ghoul et al., 2011; Goss and Roberts, 2011), bad news hoarding (Kim et al., 2014), and analyst forecast bias (Becchetti et al., 2013), while increasing operating performance (Flammer, 2015) and acquirer returns (Deng et al., 2013). Motivated by existing studies that highlight the importance of employee treatment and social schemes on corporate performance, we examine the effect that employee treatment has on corporate innovation. Since corporate innovation is one of the most important drivers of organizational long-term success (Holmstrom, 1989) and innovative output is largely dependent on human capital (Hall, 2002), understanding how employee treatment schemes affect corporate innovative output is an important research question.

Our study is based on the notion that employee treatment, a multi-dimensional employee participation and incentive scheme, is critical to corporate innovative success, even after accounting for other factors that incentivize the innovative process. We propose two main reasons why good employee treatment triggers corporate innovative success. First, innovation 
requires employees' proactive participation and teamwork (Dougherty, 1992; Van de Ven, 1986). Within a multi-unit organization, knowledge transfer across different segments provides opportunities for mutual learning and inter-unit collaboration that stimulates the creation of new ideas and new knowledge (Tsai and Ghoshal, 1998; Tsai, 2001). As a consequence, employee participation and cooperation in the innovation process is a necessary condition for the firm's innovative success. Also, as pointed out in Sauermann and Cohen (2010), nonpecuniary motives play an important role in explaining employees' innovation performance. Employee treatment schemes, such as increased employee involvement in firm decision making, offer employees greater voice in determining the firm's future perspective and stimulate them to participate in activities that enhance the firm's long-term growth and prosperity. As a result, we expect good employee treatment to be associated with more active employee participation in innovation, greater inventor teamwork, and greater inventor productivity, all of which result in better innovation performance.

Second, innovation is a long-term, multi-stage, and complex process that requires talented employees with long-term commitment (Holmstrom, 1989). By offering employees satisfying workplaces (e.g., flexible working schedules, good working conditions, attractive retirement benefits), firms can recruit and retain talented people. A satisfying workplace can also foster employee job loyalty and increase employee productivity (Black and Lynch, 2004; Bloom et al., 2011; Bloom et al., 2015). The social exchange model developed by Organ (1997) argues that employees view pleasant working conditions as a "gift" from the firm and respond with increased dedication to their job. With a firm retains talented and committed employees, the firm is better able to produce more and superior innovation that is better aligned with the firm's corporate goals and shareholders' interest. 
An alternative view on employee treatment and corporate innovation can be found in the traditional principle-agent framework developed by Jensen and Meckling (1976) and the free cash flow argument of Jensen (1986). Firms with higher free cash flows and internal reserves are likely to have more resources to wastefully invest in employee benefits. As a consequence, these firms may treat their employees more generously, even if better employee treatment does not create value for their shareholders. Cheng et al. (2014) and Masulis and Reza (2014) show that managers are more likely to be concerned with the interests of different stakeholders (including the employees) only if doing so furthers their own interests. If managers consider the improvement of employee working conditions to be beneficial to themselves (e.g., to gain a "quiet life" (Bertrand and Mullainathan, 2003)), then we would expect employee treatment to have no effect on corporate innovation.

Following recent studies in corporate finance (Verwijmeren and Derwall, 2010; Faleye and Trahan, 2011; Edmans, 2011; Bae et al., 2011), we use the Kinder, Lydenberg, and Domini Research and Analytics, Inc. (hereafter, KLD) Socrates database, which contains firm-level performance scores in relation to firms' employee treatment standards. We take a holistic view of the innovative process by relating the KLD employee treatment index to measures of the quantity and quality of firms' patent portfolios. When we examine the relation between employee treatment and patenting volume, we find strong evidence that firms with higher employee treatment scores produce more patents and patent citations in future years. Our results are insensitive to alternative employee treatment measures. These results also hold after we control for a wide range of variables that might jointly determine employee treatment and innovative activity as documented in the prior literature. Specifically, our results are robust after we control for industry unionization, state-year fixed effects, the granting of non-executive stock 
options, M\&A activity, corporate governance mechanisms, managerial characteristics (i.e., age, tenure, remuneration incentives, and overconfidence), and various measures of financial constraints. We also use Fortune's list of "100 Best Companies to Work for" as an alternative proxy for employee treatment, and we obtain consistent results. Overall, the results confirm that employee treatment is beneficial to corporate innovation.

Although we for numerous factors which can be jointly correlated with employee treatment and innovation, we further address reverse causality and omitted variable bias by performing three different tests. First, to address reverse causality concerns, we control for contemporaneous innovation in our regression and we continue to find the positive correlation between employee treatment scores and future patents and patent citations. Second, to address the omitted variable bias, we perform a change analysis. Specifically, we regress change in employee treatment index against future change in innovative output, and our results hold in the change analysis. Third, we also estimate a two-stage least squares (2SLS) regression to address the omitted variable bias. In the 2SLS specification, we use geographic asset dispersion and pension per employee lagged by five years as our instruments for employee treatment schemes. We find that the positive relation between employee treatment and a firm's innovation performance holds in the 2SLS specification. Collectively, these results suggest that our findings are robust after controlling for reverse causality or omitted variable issues.

Moreover, we conduct a sub-sample analysis based on free cash flow partitions, which shows that the impact of employee treatment schemes on innovative output is indifferent among firms with and without free cash flow problems. This test provides evidence inconsistent with the free cash flow argument.

Having established a positive association between employee treatment and innovative 
output, we also examine market value and firms' operation performance with respect to patents generated. New patents are worthless for shareholders if they cannot be converted into new products or processes that create a comparative advantage for a firm. Thus, the market's valuation of new patents signals the confidence shareholders have in the economic viability of a firm's new inventions. We find that the market values patents generated by high employee treatment firms more positively, suggesting that employee treatment facilitates not only the idea generation process but also associated new products and processes that have commercial value. Our additional analysis confirms that firms with better employee treatment schemes are better able to convert their innovative output into improvements in operating performance. Taken in their entirety, the results suggest that firms which treat their employees well are more effective at converting patented ideas into commercially successful products or processes, and that such a conversion ultimately improves firms' operating performance.

Finally, we investigate how employee treatment schemes affect innovation by studying its effects on innovation strategies, inventor efficiency, inventor turnover, and inventor teamwork. By doing so, we are able to identify the mechanism through which employee treatment facilitates innovative output. Specifically, we first examine whether the patents generated by firms which treat their employees better are tied more closely to a firm's existing knowledge base. Consistent with our expectation, we find that employee treatment schemes result in a more focused research strategy. These findings confirm that employee treatment facilitates internal communication and stimulates knowledge sharing within the organization. Next, we confirm that the employee treatment is positively correlated with inventor efficiency. We further show that better employee treatment is associated with longer inventor tenure and more efficient inventor teamwork. These findings support that better employee participation and greater job satisfaction are the two main 
channels through which employee treatment triggers corporate innovative success.

Our paper is closely related to recent studies that examine the role of employees in the innovative process. Chang et al. (2015) show that non-executive incentive schemes matter for corporate innovation. The findings presented by Chang et al. (2015) are consistent with Manso (2011) and Ederer and Manso (2013), in that they show that corporate innovation is sensitive to remuneration schemes. While Chang et al. (2015) concentrate on the monetary incentives that promote innovative output, Acharya et al. (2014) look at non-monetary incentives and find a positive association between the introduction of a legally mandated improvement in employee job protection and innovative output. Bradley et al. (2015) study the causal effect of unionization on firm innovation, and show that patent quantity and quality decreases following labor unionization. We contribute to this literature by using a more comprehensive measure of employee treatment, and show that employee treatment schemes have a distinct effect on corporate innovative success, even after excluding the two schemes documented by prior literature, i.e., job security (Acharya et al., 2014) and unionization (Bradley et al., 2015). Furthermore, by concentrating on patenting strategies and using the inventor-level patenting data, we show plausible mechanisms through which employee treatment facilitates corporate innovation.

We also contribute to the recent finance literature that examines the link between employee treatment and firm value (Edmans, 2011, 2012). Despite a positive association being documented by prior literature, little evidence is provided on the channels through which employee treatment enhances firm value. Our study fills in this apparent gap by documenting a relation between employee satisfaction and corporate innovation, and this relation has direct implications for a firm's future growth. We show that the positive relation between employee treatment and firm 
performance relies, at least in part, on the way that good employee treatment enhances the quality of a firm's innovative activities and its efficiency in converting innovative inventions to comparative advantages.

While our study reaches the same conclusion as two similar papers on the positive effect of employee treatment on corporate innovation (Mao and Weathers, 2015; Mayer et al., 2015), our study is distinct from these studies in several ways. First, we present the influence of employee treatment on not only patents and citations (both of which have been used in three studies), but also innovation strategy variables, including exploration, exploitation, depth, scope, generality and originality. ${ }^{1}$ In terms of value relevance of innovation driven by employee treatment, we follow Kogan et al. (2015) to estimate the market valuation of patents, while Mayer et al. (2015) use market-to-book ratio. All three studies employ different instrumental variables to establish causality, thereby collectively confirming the impact of employee treatment on innovation. More importantly, we use inventor data to provide individual-level evidence for the two channels through which employee treatment affects innovation performance.

\section{Data and Summary Statistics}

In this section, we describe the primary data sources and variables used in our analysis. We also offer a brief description of the summary statistics of our main variables.

\subsection{Measuring employee treatment}

We measure a firm's treatment of its employees by developing an employee treatment index based on the data obtained from the KLD Socrates database. The KLD data on employee treatment are collected from multiple sources, including company filings, government data, nongovernment organization data, general media sources, and direct communications with company

\footnotetext{
${ }^{1}$ The main dependent variables to be explained include R\&D, patent count, citation count, and innovation focus in Mao and Weathers (2015), as well as patent count, citation count, and innovative efficiency in Mayer et al. (2015).
} 
officers. Researchers use this database extensively to measure employee treatment (e.g., Landier et al., 2009; Bae et al., 2011; Ghaly et al., 2015). Firms are rated in seven major qualitative categories: environment, community, corporate governance, diversity, employee relations, human rights, and product quality and safety. There are multiple dimensions within each category, and we concentrate on five employee relation dimensions to gauge how firms treat their employees. The employee relation dimensions include: employee involvement, health and safety, retirement benefits, cash profit sharing, and other factors. ${ }^{2}$

Each dimension is associated with a strength and a concern indicator. A firm which is exceptionally good with respect to a particular dimension is assigned a value of one for the strength indicator and zero for the concern indicator. In contrast, if a firm is poor in the dimension, then a value of zero is assigned for the strength indicator and a value of one is assigned for the concern indicator. For each firm-year, we calculate the total strength and concern scores by adding the five strength indicators and the five concern indicators, respectively. The raw employee treatment index is equal to the difference between the strength score and the concern score.

Deng et al. (2013) suggest that the simple summation approach has a potential drawback: the number of strength and concern indicators for the dimensions might vary each year. Following their practice, we divide the strength and concern scores by the respective number of dimensions available in a given year and define the adjusted employee treatment index as the difference between the adjusted total strength score and the adjusted total concern score. We use the adjusted employee treatment index as our main measure of firm employee treatment. In

\footnotetext{
${ }^{2}$ To differentiate from the prior literature, we exclude no-layoff policy and union relations in constructing the employee treatment index. When we control for these two dimensions in the robustness check, we obtain consistent results.
} 
unreported tests, we find qualitatively similar results for the raw employee treatment index. ${ }^{3} \mathrm{We}$ limit our sample to the period between 1992 and 2011. The sample period starts in 1992, the earliest year for which data on employee treatment from KLD is available.

\subsection{Measuring innovation}

It is common in the economics literature to use patent data to measure firm-level innovation activities. As Griliches notes (1990, p. 1702), "Nothing else even comes close in the quantity of available data, accessibility, and the potential industrial, organizational, and technological detail." We first construct a patent data set including all patents granted to U.S. public firms from 1992 to 2014 . To do so, we first collect the patent data for patents granted in 1926-2010 from Noah Stoffman's website; this data is constructed by Kogan et al. (2015) from the United States Patent and Trademark Office (USPTO). ${ }^{4}$ The database includes the application date, grant date, and the CRSP firm identifier of the patent assignee (i.e., the firm that owns the patent) of all utility patents in the period. We then extend the patent data to all patents granted by 2014 using Google Patent database. The most challenging task is to match the CRSP firm identifiers for firms that own patents in 2011-2014. We employ an automated name matching algorithm that matches the name and location of each patent assignee that appears in 2011-2014 to a pool of names and locations that have appeared as assignees of patents listed in the NBER Patent database (Hall et al., 2001, 2005), Kogan et al. (2015), and Google Patent database. As a result, we are able to use the detailed information of U.S. public firms' patents granted from 1992 to 2014. Since we use the application year as the effective time placer of innovation

\footnotetext{
${ }^{3}$ As an additional robustness check, we construct numerous alternative measures of employee treatment. Specifically, we exclude the cash profit sharing and retirement benefits components from our index, as they may arguably be explicit in nature in some firms. Second, consistent with Bae et al. (2011) and Ertugrul (2013), we use an index that includes strength variables only. Third, we use an industry-adjusted employee treatment index to overcome the problem of industry-determined levels of employee satisfaction. When we use these different measures, we obtain consistent results.

${ }^{4}$ Link to the website: https://iu.app.box.com/patents.
} 
performance, we drop observations over the last three years from the end year of the dataset to overcome the truncation bias (Hall et al., 2001, 2005; Dass et al., 2015). This step limits our sample to the period 1992-2011.

Our first primary measure of innovative output is patent count, defined as the natural logarithm of one plus the number of patents granted for each firm in each year. Although innovative output is not directly observable, the patents that firms apply for (and that are eventually approved by the USPTO) offer a good indicator of firms' level of innovative inventions (i.e., patents can only be granted if an invention is novel, non-trivial, and has commercial application). Economists have traditionally used patent events to measure firm-level innovation performance (Scherer, 1965a, 1965b), and as Kamien and Schwartz (1975) conclude in their review article, "systematic study of patenting behavior has led Schmookler, Scherer, and others to conclude that the number of patents granted a firm is a usable proxy for inventive outputs." (p. 5).

A simple patent count captures innovative success imperfectly because patents vary widely in their technological and economic significance. Citations made to a firm's patents can better reflect those patents' technological or economic significance (Trajtenberg, 1990; Hall et al., 2005). For this reason, the second primary measure of innovative output is citation count, which is defined as the natural logarithm of one plus the number of citations generated by patents filed by each firm in each year. However, owing to the finite length of our sample, citations suffer from a truncation bias: because citations are received for many years after a patent is created, patents created in later years have less time to accumulate citations than patents created in earlier years. To address this issue, we adjust the citation count of each patent using the weighting index 
from Hall et al. (2001, 2005). The weighting index is created using a quasi-structural approach in which the shape of the citation-lag distribution is econometrically estimated.

\subsection{Firm-level controls}

We include a number of firm-level controls in our regression analysis. ${ }^{5}$ Following Hall and Ziedonis (2001), we control for firm size and capital intensity. Firm size is defined as the natural logarithm of total assets. Capital intensity is measured by the natural logarithm of the ratio of net property, plant, and equipment over the number of employees. Consistent with the extant literature (e.g., Chang et al., 2015; He and Tian, 2013; Hirshleifer et al., 2012), we include capital expenditure, return on assets (ROA), book leverage, sales growth, market-to-book ratio, cash holdings, firm age, and industry competition in all of our regressions. Specifically, ROA is the ratio of operating income over book assets. Book leverage is the ratio of total debt over book assets. Sales growth is the annual sales growth rate. Market-to-book ratio is the ratio of market value of equity over book value of equity. Capital expenditure is defined as capital expenditure over total assets. Cash holding is measured as the cash holding over total assets, and we define firm age as the difference between the current year and the first year the firm appears in the Compustat database. Finally, we use the Herfindahl index and its square term to measure industry competition.

We further control for R\&D intensity to capture the relation between employee treatment and patenting activity, which is independent of a firm's investment in innovation. R\&D spending is scaled by book assets, with missing $\mathrm{R} \& \mathrm{D}$ values being assigned a value of zero. ${ }^{6}$ Because this

\footnotetext{
${ }^{5}$ In the analysis, all the independent variables, including our interested variable and control variables, are lagged by one year relative to the dependent variable.

${ }^{6}$ This approach is consistent with Hirshleifer et al. (2012), and is based on the notion that R\&D spending not reported on a separate line item does not pass the materiality threshold under GAAP.
} 
approach can introduce potential bias, we include an indicator variable equal to one when a missing value is replaced by zero.

We also control for institutional ownership. Aghion et al. (2013) show that institutional ownership benefits innovative output through its mitigating effect on CEO myopia. Institutional ownership data are based on quarterly common stock holdings of 13(f) institutions, as indicated by Thomson Reuters. Our measure of institutional ownership is the number of shares held by institutional investors divided by the total number of shares outstanding. Finally, we collate data on analyst coverage. He and Tian (2013) find that firms covered by a larger number of analysts generate fewer patents with lower impact. The data on analyst coverage come from the I/B/E/S Historical Summary File. For each firm-year observation, analyst coverage is set equal to the average number of $\mathrm{I} / \mathrm{B} / \mathrm{E} / \mathrm{S}$ analysts who provide earnings estimates over the four quarters of each calendar year. Variable definitions can be found in Appendix A.

\subsection{Descriptive statistics}

Panels A and B of Table 1 provide summary statistics of the main variables used in this study. With respect to employee treatment (i.e., our variable of interest), the average score is 0.04 with a median score of 0 . This observation suggests that the average firm has poor employee treatment schemes in place, with the median firm having neutral employee treatment schemes. These findings are consistent with prior studies (Bae et al., 2011; Deng et al., 2013).

\section{[Insert Table 1]}

In Panel $\mathrm{C}$, we partition the sample into high and low employee treatment firms and calculate the difference in means of our two primary measures of innovative output; patent count and citation count. The high employee treatment sub-sample comprises firms which have positive employee treatment scores, while the low employee treatment sub-sample comprises 
firms which have negative employee treatment scores. The univariate tests show that innovative output in the high employee treatment sub-sample is considerably higher compared with the low employee treatment sub-sample. The differences in means for both measures of innovative output are statistically significant at the 1 percent level, providing preliminary support to a positive relation between employee treatment and corporate innovative success.

\section{Employee Treatment and Innovative Activity}

In this section, we perform regression analyses on the relation between employee treatment and innovative output. We first present the main regression results followed by a comprehensive set of robustness tests that validate our baseline results. To address endogeneity concerns, we then employ both a change analysis framework as well as a two stage least squares (2SLS) framework.

\subsection{Baseline results}

The baseline results are presented in Table 2. The dependent variable in columns (1) and (2) is log patent count (LnPat), and the dependent variable in columns (3) and (4) is log citation count (LnCit). The regression model in columns (1) and (3) include all firm-level control variables discussed in section 2.3 with the exception of the two R\&D intensity variables. Columns (2) and (4) control for these two variables. We adopt a lead-lag regression, and let all independent variables--including our interested variable and control variables--be lagged by one year relative to the dependent variable. Across all regressions, industry and year fixed effects are included. ${ }^{7}$ Standard errors, corrected for clustering at the firm level, are reported in parentheses.

\footnotetext{
${ }^{7}$ We do not control for firm fixed effects as our employee treatment index is quite sticky over time for each particular firm. We note that innovation varies across firms to a great extent, as the cross-sectional (cross-firm) variation in innovation is likely greater than time-series (cross-year) variation in innovation within a firm. Thus, using a level regression including firm fixed-effects may not help us to detect the significance of a sticky determinant (employee treatment) of corporate innovation (Hall et al., 2005, 2007; Noel and Schankerman, 2013). We thus adopt two alternative specifications in later analyses to mitigate the concern of firm-level heterogeneity. First, we conduct change analysis by regressing changes in innovation on changes in employee treatment. By doing
} 


\section{[Insert Table 2]}

In column (1), the coefficient estimate of employee treatment, our variable of interest, is positive and significant at the 1 percent level. In economic terms, the coefficient estimate of 0.42 suggests that a one-standard-deviation increase in the level of the employee treatment index is associated with a 0.071 increase in the log patent count. This finding represents an increase of over 7 percent in patent output relative to its cross-sectional mean, which is economically significant as the average logged patent number in our sample is 1.01 . The results reported in column (1) suggest that employee treatment is an important factor which facilitates firms' patenting activities. The results in column (2) are similar when we include the R\&D intensity into our baseline model.

The regression results reported in columns (3) and (4) summarize the link between the employee treatment index and the significance of innovative inventions as proxied by citation count. The results are largely consistent with those reported in columns (1) and (2). The coefficient estimate on the employee treatment index is 0.50 and significant at the 1 percent level. Thus, a one-standard-deviation increase in the employee treatment index is associated with a corresponding increase in the log citation count of roughly 5.5 percent relative to its crosssectional mean. The results in column (4) are similar once we include R\&D intensity into our baseline model. Overall, the results suggest that the employee treatment index has a positive effect on the significance of innovative output generated by firms. The magnitude of the economic significance of employee treatment on innovation is similar to the effect of analyst

so, the cross-firm variation is differenced away, which allows us to focus on the time-series variation. Second, we control for the persistence of innovation variables by including a current innovation variable as a control in our regressions. This way, we control for firm-specific heterogeneity that should exist in both the dependent variable (future innovation) and a control variable (current innovation). 
following (He and Tian, 2013), local gambling preferences (Chen et al., 2014), and managerial ability (Chen et al., 2015).

\subsection{Basic robustness checks}

In this section, we first check the robustness of our results and address the omitted variable problem. We then demonstrate the tests to control for reverse causality. The basic robustness test results are reported in Table 3, which presents the coefficient estimates and standard errors on employee treatment, our variable of interest, together with the adjusted R-square and the number of observations in different specifications. Two sets of regression tests are reported. The tests are based on the baseline model specifications from columns (2) and (4) in Table 2 (i.e., regression models include the full set of control variables, including R\&D intensity).

\section{[Insert Table 3]}

The first two robustness tests we perform examine whether our results are sensitive to alternative measures of employee treatment. In Panel A, we reconstruct the employee treatment variable by including the no lay-off policy and unionization components in our index. We find that this alternative employee treatment index generates qualitatively similar results to those obtained in the baseline model. The statistical significance remains unchanged, though the magnitude of the coefficient estimate increases. In Panel B, we follow Bae et al. (2011) and use only the strength indicators in constructing the index, without taking into account the concern indicators. We find that constructing the employee treatment index based solely on strength indicators considerably strengthens our results, both economically and statistically.

Next, we try to address the potential omitted variable bias by controlling for numerous additional factors which we omit from our baseline tests. In Panel $\mathrm{C}$, we control for the level of industry unionization. Bradley et al. (2015) find that unionization has a negative effect on 
innovation. Since the level of industry unionization might be correlated with firm-level employee treatment schemes, any relation that we report between employee treatment and innovation could be fundamentally driven by the level of industry unionization. However, our results are inconsistent with this conjecture, as the effect of employee treatment on innovation is largely unaffected by including this additional control, except for a small change in the magnitude of the coefficient.

In Panel D, we include state-year fixed effects in regressions that capture all time-varying, state-specific factors, including the state-level wrongful discharge laws of Archarya et al. (2014). The results in Panel D reveal that our results are robust to the inclusion of state-year joint fixed effects, which suggests that positive employee treatment schemes have an incremental effect on innovation after we control for all time-varying state-specific factors.

In Panel E, we explicitly control for non-executive employee stock option grants. Chang et al. (2015) show that the granting of non-executive stock options has a positive impact on innovative output. At the same time, monetary incentives could be introduced in tandem with non-monetary incentives. To ensure that our results are not driven by the monetary incentive effect reported in Chang et al. (2015), we control for the grant of rank-and-file employee stock options, as shown in Panel E. The inclusion of non-executive stock options reduces our sample to 2,223 observations. Nevertheless, the results remain qualitatively unchanged relative to the baseline results, suggesting that as one form of non-monetary incentives, employee treatment schemes have an incremental effect on innovation beyond the effect of monetary incentives; this finding is consistent with Sauermann and Cohen (2010), who find that nonpecuniary motives play an important role in explaining employees' innovation performance. 
In Panel F, we control for firms' M\&A activity in the previous two years to make sure that the increase in innovative activity is not obtained through acquisitions. ${ }^{8}$ In our empirical analysis, we include an indicator variable that is assigned a value of one if the firm was involved in any M\&A activity over the previous two years to account for the impact of takeovers. After we control for M\&A activity, our results remain unchanged.

In Panel G, we control for corporate governance factors. Corporate governance helps ameliorate managers' wasteful spending. If our results are spurious due to agency problems that jointly drive better employee treatment and greater innovative activity, then accounting for corporate governance should address this issue. We control for the E-Index, Hostile index, CEO duality, and board independence. Specifically, Bebchuk et al. (2009) proposed the E-index, which is based on firm anti-takeover provisions. Also Cain et al. (2015) develop the Hostile index, which is constructed from the full array of takeover laws. CEO duality is a dummy variable equal to one if the $\mathrm{CEO}$ and the chairman of the board are the same individual and zero otherwise. Board independence is measured by the proportion of independent directors in the board. We obtain the data of the three variables from RiskMetrics. The hostile index data is obtained from Stephen McKeon's website. ${ }^{9}$ The results stay unchanged after controlling for the corporate governance measures.

In Panel H, we control for CEO characteristics. Hirshleifer et al. (2012) show that managerial characteristics have the potential to influence innovative activity. At the same time, managerial characteristics can influence how firms treat their employees. For example, Galasso and Simcoe (2011) and Hirshleifer et al. (2012) show that managerial overconfidence is an important determinant of innovative activity. These studies show that CEOs' personal traits can

\footnotetext{
${ }^{8}$ Deng et al. (2013) show that firms performing well with respect to their social responsibility are better able to integrate target firms into their organization. This raises the possibility that M\&A activity is driving our results.

${ }^{9}$ Link to the website: http://pages.uoregon.edu/smckeon.
} 
have a significant impact on firms' innovative success. Thus, managerial characteristics could be the real driving force behind the baseline results. To address this concern, we control for managerial characteristics in Panel $\mathrm{H}$. These additional controls include CEO age, tenure, overconfidence, and gender. Following Malmendier and Tate (2008), we define a CEO as overconfident once he or she postpones the exercise of vested options that are at least 67 percent in-the-money, and we follow Campbell et al. (2011) to calculate this variable. We find that these additional controls do not alter our main findings.

In Panel I, we control for the remaining categories of corporate social responsibility (CSR) reported in the KLD database. Specifically, we construct a CSR index based on the remaining categories pertaining to environment, community, corporate governance, diversity, human rights, and product quality and safety. Employee treatment category may be highly correlated with other categories of corporate social responsibility, and these other categories may subsume the effect that employee treatment has on innovation. However, the results reported in Panel I show this not to be the case. Even after we control for these remaining components of corporate social responsibility, the coefficient estimates on our employee treatment index are still positive and significant.

We explicitly address reverse causality in Panels J, K, and L. In these tests, we control for contemporaneous innovation output (innovation at the same time period that the independent variables are measured), and measure innovative output using different time-leads (from $t+1$ in Panel $\mathrm{J}$, as in the baseline specifications, to $t+2$ and $t+3$ in Panels $\mathrm{K}$ and $\mathrm{L}$, respectively). We do so because controlling for contemporaneous innovation output makes it difficult for future innovation to explain current employee treatment, given that current innovation should already capture a firm's innovative "potential" and "prospect" (Hsu et al., 2015). The results in Panel J, 
$\mathrm{K}$, and $\mathrm{L}$ remain qualitatively unchanged after we control for contemporaneous innovative output. The fact that the results remain unchanged, even when innovation output is measured at $t+2$ and $t+3$, further suggests that the results are not driven by reverse causality.

In Panels $\mathrm{M}, \mathrm{N}$, and $\mathrm{O}$, we further control for financial constraints. Less constrained firms are more able to invest generously in their employees and also into R\&D. Therefore, without controlling for financial constraints, our main findings might merely indicate a spurious correlation. To account for this possibility, we control for three different proxies of financial constraints: the WW index, the KZ index, and the HP index developed by Whited and Wu (2006), Kaplan and Zingales (1999), and Hadlock and Pierce (2010), respectively. Our results hold after we control for different measures of financial constraints.

\subsection{Further Discussion of Endogeneity}

Although the results presented up to this point are strong and robust, endogeneity concerns are not fully alleviated. In Tables 2 and 3, we have included a vast array of control variables and have explicitly addressed reverse causality. However, we still cannot entirely rule out the possibility that omitted variables are driving our results, or that reverse causality is in play. To further address these concerns, we use a change analysis and an instrumental variables approach framework. The results of our change analysis are presented in Table 4.

\section{[Insert Table 4]}

In Table 4, we convert all our variables into first differences. For example, the dependent variable LnPat is converted from a level variable to the change in LnPat for firm $i$ between $t$ and $t+1$. Likewise, all independent variables are converted from level variables to changes between $t$ 1 to $t$. The benefit of such a change analysis relative to the level analysis is that cross-sectional variation in firms is differenced away, which allows us to focus on the time-series variation. As a 
consequence, both reverse causality and omitted variable bias is alleviated in this setting. The results presented in Table 4 show that the positive and significant relation between employee treatment and innovative output hold in the change analysis setting.

In addition to performing this change analysis, we also employ a 2SLS methodology. We use two instruments for employee treatment. The first is the proportion of assets of a firm's geographic segments. Landier et al. (2009) show that geographically dispersed firms are less employee friendly compared to less dispersed firms. Indeed, in the first stage regression, we find that a geographic dispersion of assets is very strongly negatively related to employee treatment. Geographic dispersion is not expected to be related to patenting activity other than through its impact on employee treatment, and therefore satisfies the exclusion restriction. The second instrument is pension expense per employee lagged by five years. Bae et al. (2011) show a strong positive relation between the pension expense per employee five years ago and the current employee treatment score. The second instrumental variable is also expected to meet the exclusion restriction, with the previous pension expense expected to affect innovative activity exclusively through its effect on employee satisfaction. The second stage coefficients on the predicted values of employee treatment are reported in columns (1) and (2) of Panel A, as well as columns (4) and (5) of Panel B, Table 5. We find that the predicted employee treatment index is positively related to patenting activity, with the coefficient estimate being significant at the 1 percent level. We also conduct the Sargan test and the results do not reject our null hypothesis that two instrumental variables are uncorrelated with the error term. We find consistent results when we include R\&D intensity in the 2SLS framework (Panel B). Collectively, these analyses lead us to conclude that employee treatment has a causal effect on corporate innovation.

\section{[Insert Table 5]}




\section{Further Analysis}

\subsection{Using Fortune's “100 Best Companies to Work For” list as a proxy for employee treatment}

To obtain results so far in this paper, we have used the KLD database to generate the employee treatment index. Although this approach is prevalent in the finance literature, we now examine whether we obtain consistent results when we employ an alternate proxy for employee treatment. In particular, we replace the employee treatment index with a dummy variable that is equal to one if the firm is listed in Fortune magazine's list of the "100 best companies to work for". Prior studies have used this measure of employee satisfaction as an alternative to the KLDbased index (Faleye and Trahan, 2011; Edmans, 2011; Bae et al., 2011). Fortune creates its list by combining employee surveys and company responses. Two-thirds of a firm's score is based on an extensive employee survey, which asks questions pertaining to employees' attitudes towards management credibility, job satisfaction, and camaraderie. The remaining one-third of the score is based on the company's responses to the institute's Culture Audit, which includes detailed questions on demographic makeup, pay, and benefit programs, as well as the company's management philosophy, methods of internal communication, opportunities, diversity effort, and other factors.

\section{[Insert Table 6]}

Using two different approaches, we employ the Fortune 100-based proxy of employee treatment using two approaches. First, we simply identify the firm-years in which a firm is included in the list and code these firms with one. All remaining firm-years are coded with zero. We then regress innovative output on the Fortune 100 proxy, using the entire sample with available data. The results, reported in columns (1) and (2) of Table 6, show a positive relation between inclusion in Fortune's list and future innovative output. Second, we perform propensity 
score matching to ensure that control firms have similar characteristics to those firms which are included in Fortune's list. ${ }^{10}$ The premise of the propensity score matching approach is that these control firms are similar to the treatment firms in all matching dimensions, but are not in the list due to lower levels of employee treatment. In addition, the use of the matched sample (including both treatment firms and control firms) helps mitigate the sample imbalance issue since there are only 100 firms included in the list. ${ }^{11}$ The results that we obtain with the propensity score matching approach appear in columns (3) and (4) of Table 6. In both columns, the coefficient estimates of Fortune 100 variable remain positive and significant. Overall, Table 6 suggests that our findings are robust to alternative proxies of employee treatment.

\subsection{The effect of free cash flow}

In this paper, we propose and test two competing hypotheses that explain how employee treatment affects corporate innovation. The first hypothesis is that employee treatment enhances corporate innovation, since employee treatment enhances employee participation and employee satisfaction in the innovation process. The alternative hypothesis is that employee treatment schemes are simply a consequence of free cash flow, in that managers wastefully invest in improved employee treatment schemes to improve their reputation as well as to have a "quieter life" (Bertrand and Mullainathan, 2003). Although we find a strong and robust positive relation between employee treatment and innovative output that is contrary to the alternate hypothesis, in this sub-section, we explicitly evaluate whether the relation between employee treatment and innovation differs between firms with and without a free cash flow problem.

\footnotetext{
${ }^{10}$ We calculate the probability of inclusion in the Fortune 100 list as a function of free cash flow, cash holdings, ROA, CSR score, market-to-book value, SG\&A-per-employee expenses, as well as industry and year fixed effects. Each treatment firm is matched to its three closest control firms (where the difference in propensity score does not exceed 1 percent).

${ }^{11}$ Since the Fortune 100 list consists of both public and private firms, the number of public firms in the list is actually fewer than 100 .
} 
We construct an indicator variable equal to one when free cash flow is positive, and zero otherwise. ${ }^{12}$ We then interact this variable with the employee treatment index. As such, the coefficient of the employee treatment index captures the effect that employee treatment has on corporate innovation among firms without a free cash flow problem (i.e., free cash flow is zero or negative). The interaction term tells us how this relation changes among firms with a free cash flow problem. For brevity's sake, we only report the variables of interest when we present our results in Table 7, although the model specification is identical to the baseline setting.

\section{[Insert Table 7]}

Our results suggest that the free cash flow problem is irrelevant for the relation between employee treatment and innovative output. Across both measures of innovative output, the coefficient estimate on the employee treatment index is positive and significant at the 1 percent level, while the coefficient estimate on the interaction term is insignificant at conventional significance levels. Thus, we conclude that the free cash flow argument is not supported by our empirical evidence.

\subsection{Employee treatment and market valuation of patents}

So far, our results show that employee treatment has a positive effect on innovative output and that this effect is independent of either free cash flow or financial constraints. Nevertheless, our analysis up to this point does not shed any light on the effect that employee treatment has on commercial success. Addressing this vital question is somewhat limited by data availability, for the patent data only allows us to examine a firm's innovative activity up to the idea generation phase. In reality, innovative activity is worthless if new ideas cannot be converted into new products or processes which give a firm a comparative advantage. When examining the effect of

\footnotetext{
${ }^{12}$ Free cash flow is defined as the sum of income before extraordinary items plus depreciation and amortization less cash dividends less equity dividend paid less capital expenditures or additions to fixed assets.
} 
employee treatment on the innovative process, the ultimate question is whether employee treatment increases firm value through innovation. We address this important question using market reactions to patent announcements. Specifically, we assume that the market provides the most unbiased estimate of the value of a firm's patents, with a higher market valuation reflecting higher profits from converting patents into valuable new products and processes. We therefore develop numerous measures of a patent's market value.

We follow Kogan et al. (2015) and measure patent value as the increase in market value in the three-day period of patent announcements after we adjust for benchmark return, idiosyncratic stock return volatility, and various fixed effects. The benchmark return is a market return, a 2digit SIC code industry return, or a Fama-French 48 industry return. We then sum the value of all patents filed by each firm in each year to be the value of patents that a firm generates, and then take the natural logarithm of that value plus one.

\section{[Insert Table 8]}

In Table 8, we report the regression results that show the relation between employee treatment and patent value. In each column, we use an alternate measure of patent value. The regression model incorporates all firm-level controls as well as industry and year fixed effects. The results reveal a strong positive association between employee treatment and patent value. Across all columns, the coefficient estimates on the employee treatment index are positive and significant at the 1 percent level. The results therefore reveal that firms with better employee treatment schemes not only generate more patents, but that the patents they generated carry higher economic value. This finding suggests that positive employee treatment schemes are beneficial to shareholders. 


\subsection{Employee treatment and operating performance}

In this section, we examine whether the innovative activities of employee-friendly firms improves firms' operating performance. In particular, we partition the sample into employeefriendly and employee-unfriendly sub-samples. The high employee treatment sub-sample comprises firms that have a positive employee treatment score, while the low employee treatment sub-sample comprises firms which have a negative employee treatment score. In each sub-sample, we relate contemporaneous innovative output (i.e., log patent count and log citation count) with future operating performance. Operating performance is defined as the natural logarithm of one plus the growth rate in ROA over a five-year period between $t$ and $t+5$. The results are reported in Table 9.

\section{[Insert Table 9]}

The results reveal that patent output has a considerably stronger effect on future operating performance when firms are employee-friendly. In particular, while the coefficient estimates on both measures of innovative output are positive and significant in the high employee treatment sub-sample, the coefficient estimates on the innovative output variables are insignificant in the low employee treatment sub-sample. These results reveal that the way that firms treat their employees strongly influence firms' operating performance with respect to innovation.

\subsection{Employee treatment and innovation strategies}

While we have established so far that better employee treatment results in firms generating more and superior patents of higher market value, we have not looked at the heterogeneity in innovative output. In this section, we examine the effect that employee treatment has on the innovation strategies that firms pursue. 
To analyze the effect that employee treatment has on innovation heterogeneity, we employ the following measures: exploitation, exploration, depth, scope, generality, and originality. Following Benner and Tushman (2002), we define a patent as exploitative if $60 \%$ or more of its citations reflect a firm's existing expertise, which is defined as the combination of the firm's existing patents or the citations made by those patents. Exploitation is the ratio of exploitative patents to the total number of patents applied for by firm $i$ in year $t$. In contrast, we define a patent as exploratory if $60 \%$ or more of its citations do not reflect a firm's existing expertise. Exploration is the ratio of exploratory patents to the total number of patents applied for by firm $i$ in year $t$. Prior research suggests that, both exploitation and exploration are generally essential for organizational survival and prosperity (Benner and Tushman, 2002; Gupta et al., 2006; McGrath, 2001). However, these two forms of innovation diff fundamentally in focus: while exploratory strategy highlights new technology development beyond a firm's existing expertise, exploitative strategy focuses on path-dependence and a firm's deepening of its existing expertise.

Following Katila and Ahuja (2002) and Chen et al. (2015), we define the depth variable as a ratio of the number of repeated citations made by patents a firm applied for in year $t$ divided by the total number of citations made by all patents a firm applied for in year $t$. Repeated citations are citations that have been made by the firm in the past five years. Higher depth from the use of more repeated citations suggests that a firm's innovative activities are more concentrated in its existing knowledge. In contrast, the scope variable is the ratio for the number of new citations made by patents that a firm applied for in year $t$ divided by the total number of citations made by all patents a firm applied for in year $t$. New citations are citations that have never been made by the firm in the past five years. Higher scope from the use of these newer citation suggests that a firm's innovative activities tend to reflect new knowledge. 
Finally, the generality variable is the median of the generality scores of all patents filed by firm $i$ in year $t$. Following Trajtenberg et al. (1997), we calculate the generality score of a patent as one minus the Herfindahl index of the technical category distribution of all patents that have cited this particular patent. In contract, the originality variable is the median of originality scores of all patents filed by firm $i$ in year $t$. Following Trajtenberg et al. (1997), we define the originality score of a patent as one minus the Herfindahl index of the technology category distribution of all patents that have been cited by this particular patent. Patent generality indicates how broadly a patent can be applied in other technology classes, while patent originality reflects the extent to which a patent is distinct from an extant technology class.

\section{[Insert Table 10]}

The results on the relation between employee treatment and the different innovation strategies are presented in Table 10. The results show that employee treatment is positively associated with the number of exploitative patents and negatively associated with the number of exploratory patents. At the same time, employee treatment is positively associated with the depth of the patents and negatively associated with the scope of the patents. Finally, we find a positive relation between employee treatment and patent generality, although we find no relation between employee treatment and patent originality. Overall, our results suggest that treating employees well encourages them to work harder in their existing expertise, rather than pursue new expertise.

\section{Channel Tests}

In this section, we examine the specific channels through which positive employee treatment affects corporate innovative output. In our hypothesis development, we argue that employee treatment results in increased innovative output since inventor productivity is higher among firms that treat their employees better. We argue that improved inventor productivity is a 
consequence of lower inventor turnover as well as increased teamwork among numerous inventors that a firm employs. We explicitly examine these channels in this section, and we report the results of our channel analysis in Table 11.

\section{[Insert Table 11]}

Panel A of Table 11 illustrates the relation between employee treatment and inventor productivity. Since our argument revolves around employee treatment schemes improving inventor productivity, we first need to establish that this is indeed the case. To do so, we measure inventor productivity by first calculating the number of inventors that work for a given firm at any given point in time. Using the Harvard Business School (HBS) Patent and Inventor database, we identify an inventor as employed by a particular firm at time period $t$ if he or she files at least one patent for this firm during $t-3$ to $t$ and files at least one patent during $t$ to $t+3$. Then, we define patents per inventor (citations per inventor) by dividing the number of patents (citations) in year $t$ by the total number of inventors employed by the firm in year $t$. We then relate our two measures of inventor efficiency to our employee treatment index. The results in Panel A of Table 11 reveal that employee treatment is positively associated with inventor efficiency. When coupled with our earlier findings that employee treatment leads to more exploitative patents and higher depth, our findings are consistent with Almeida et al. (2013), for we show that innovation efficiency tends to increase with exploitation and depth. Furthermore, the results are intuitive, as firms would find it more efficient to produce new patents that are related, given the steep learning curve.

Having established that positive employee treatment is associated with improved inventor productivity, we next examine whether this improvement in inventor productivity is indeed generated by reduced turnover and improved teamwork. In Panel B of Table 11, we examine the 
relation between employee treatment and the average tenure of inventors. We measure average tenure as the average number of years that inventors stay with a firm. We then run a pure crosssectional regression, in which the dependent variable is the natural logarithm of the average number of years that inventors stay with the firm (one data point per firm) and the independent variables are the firm-level averages of the full set of control variables. For example, the employee treatment variable is the average employee treatment index across time for each individual firm. We include industry fixed effects into our regression. Our results show that employee treatment is positively associated with average tenure, which suggests that firms that treat their employees better manage to keep their employees for longer.

In Panel $\mathrm{C}$, we examine whether employee treatment is also associated with improved teamwork. To test this channel, we relate employee treatment with the natural logarithm of one plus the number of inventors (employed by the firm) per patent. The idea behind this test is that greater collaboration and teamwork should manifest itself through a greater number of a firm's employees being involved in each patent (Singh and Fleming, 2010). Our results show this to be the case, as employee treatment is positively associated with the number of inventors per patent.

In Table 11, we show that the positive relation between employee treatment and corporate innovation is--to a large extent--the consequence of improved inventor productivity, lower inventor turnover, and greater teamwork among a firm's inventors.

\section{Conclusion}

Because innovation is a key driver of economic growth, understanding the determinants of corporate innovation is essential. In this study, we explore whether adopting better employee treatment schemes helps a firm's innovation success. Employees are crucial to corporate innovation, and firms that offer employees a greater voice motivate employees to participate 
more actively and creatively in the innovation process. By offering their employees satisfying workplaces, firms can also recruit and retain talented people who play key roles in innovative activities. Therefore, we expect better employee treatment schemes to be associated with both a higher quantity and quality of innovation.

Using the employee treatment index from the KLD database, we find evidence that employee-friendly firms produce greater innovative output compared with firms which treat their employees more poorly. Our results are robust to alternative model specifications and endogeneity concerns. We further find that firms which treat their employees well have a higher market value of patents and that the impact of these patents on operating performance is greater for these firms. Our findings demonstrate that better employee treatment is associated with a more effective conversion of patented ideas into commercial success, which improves operating performance. In additional tests, we find that better employee treatment results in more focused, deeper, and more general innovation strategies. Better employee treatment is also associated with higher inventor efficiency, longer inventor tenure, and greater inventor teamwork. These findings support our proposed channels through which employee treatment affects corporate innovation.

Our study contributes to the employee treatment literature by identifying a channel through which better employee treatment enhances firm value. The study also contributes to the corporate innovation literature by suggesting the essential role of employees in innovation success. We supplement the literature by highlighting an important employee incentive in corporate innovation. 


\section{Reference}

Acharya, V., Baghai, R., Subramanian, K., 2014. Wrongful discharge laws and innovation. Rev. Financ. Stud. 27, 301-47.

Aghion, P., Van Reenen, J., Zingales, L., 2013. Innovation and institutional ownership. Am. Econ. Rev. 103, 277-304.

Almeida, H., Hsu, P., Li, D., 2013. When less is more: Financial constraints and innovative efficiency. Working paper.

Bae, K., Kang, J., Wang, J., 2011. Employee treatment and firm leverage: A test of the stakeholder theory of capital structure. J. Financ. Econ.100, 130-153.

Bebchuk, L., Cohen, A., Ferrell, A., 2009. What matters in corporate governance? Rev. Financ. Stud. 22, 783-827.

Becchetti, L., Ciciretti, R., Giovanelli, A., 2013. Corporate social responsibility and earnings forecast unbiasedness. J. Bank. Finan. 37, 3654-3668.

Benner, M., Tushman, M., 2002. Process management and technological innovation: A longitudinal study of the photography and paint industries. Adm. Sci. Q. 47, 676-706.

Bertrand, M., Mullainathan, S., 2003. Enjoying the quiet life? Corporate governance and managerial preferences. J. Polit. Econ. 111, 1043-1075.

Black, S., Lynch, L., 2004. What's driving the new economy? The benefits of workplace innovation. Econ. J. 114, 97-116.

Bloom, N., Kretschmer, T., Van Reenen, J., 2011. Are family-friendly workplace practices a valuable firm resource? Strateg. Manag. J. 32, 343-367.

Bloom, N., Liang, J., Roberts, J., Ying, Z.J., 2015. Does working from home work? Evidence from a Chinese experiment. Q. J. Econ. 130, 165-218.

Bradley, D., Kim, I., Tian, X., 2015. The causal effect of labor unions on innovation. Manag. Sci., forthcoming.

Campbell, C., Gallmeyer, M., Johnson, S., Rutherford, J., Stanley, B., 2011. CEO optimism and forced turnover. J. Financ. Econ.101, 695-712.

Cain, M.D., McKeon, S.B., Solomon, D.S., 2015.Do takeover laws matter? Evidence from five decades of hostile takeovers. Working paper.

Chang, X., Fu, K., Low, A., Zhang, W., 2015. Non-executive employee stock options and corporate innovation. J. Financ. Econ.115, 168-188.

Chen, G., Gao, H., Hsu, P., Li, K., 2015, Ownership transition, managerial short-termism, and exploratory versus exploitative innovation strategy. Working paper.

Chen, Y., Podolski, E.J., Rhee, S.G., Veeraraghavan, M., 2014. Local gambling preferences and corporate innovative success. J. Financ. Quant. Anal. 49, 77-106.

Chen, Y., Podolski, E.J., Veeraraghavan, M., 2015. Does managerial ability facilitate corporate innovative success? J. Empiric. Finan. 34, 313-26.

Cheng, I., Hong, H., Shue, K., 2014. Do managers do good with other people's money? Working paper.

Dass, N., Nanda, V., Xiao, S., 2015. Truncation Bias in Patent Data: Does it Explain Why StockLiquidity Seemingly Reduces Innovation? Working paper.

Deng, X., Kang, J., Low, B., 2013. Corporate social responsibility and stakeholder value maximization: Evidence from mergers. J. Financ. Econ.110, 87-109. 
Dougherty, D., 1992. Interpretive barriers to successful product innovation in large firms. Org. Sci. 3, 179-202.

Ederer, F.P., Manso, G., 2013. Is pay-for-performance detrimental to innovation? Manag. Sci. 59, 1496-513.

Edmans, A., 2011. Does the stock market fully value intangibles? Employee satisfaction and equity prices. J. Financ. Econ.10, 621-640.

Edmans, A., 2012. The link between job satisfaction and firm value, with implications for corporate social responsibility. Acad. Manag. Pers. 26, 1-9.

Ertugrul, M., 2013. Employee-friendly Acquirers and Acquisition Performance. J. Financ. Res. 36, 347-370.

Faleye, O., Trahan, E., 2011. Labor-friendly corporate practices: Is what is good for employees good for shareholders? J. Bus. Ethics 101, 1-27.

Flammer, C., 2015. Does corporate social responsibility lead to superior financial performance? A regression discontinuity approach. Manag. Sci. 61, 2549-68.

Galasso, A., Simcoe, T., 2011. CEO overconfidence and innovation. Manag. Sci. 57, 1469-1484.

Ghaly, M., Dang, V., Stathopoulos, K., 2015. Cash holdings and employee welfare. J. Corp. Financ. 33, 53-70.

Ghoul, S., Guedhami, O., Kwok, C., 2011. Does corporate social responsibility affect the cost of capital. J. Bank. Finan. 35, 2388-2406.

Goss, A., Roberts, G., 2011. The impact of corporate social responsibility on the cost of bank loans. J. Bank. Finan. 35, 1794-1810.

Griliches, Z., 1990. Patent statistics as economic indicators: A survey. J. Econ. Lit. 28, 16611707.

Gupta, A., Smith, K., Shalley, C., 2006. The interplay between exploration and exploitation. Acad. Manag. J. 49, 693-706.

Hadlock, C., Pierce, J., 2010. New evidence on measuring financial constraints: Moving beyond the KZ index. Rev. Financ. Stud. 23, 1909-1941.

Hall, B., 2002. The financing of research and development. Oxf. Rev. Econ. Policy 18, 35-51.

Hall, B., Jaffe, A., Trajtenberg, M., 2001. The NBER patent citations data file: Lessons, insights and methodological tools. NBER Working Paper Series.

Hall, B., Jaffe, A., Trajtenberg, M., 2005. Market value and market citations. RAND J. Econ. 36, $16-38$.

Hall, B., Thoma, G., Torrisi, S., 2007. The market value of patents and R\&D: Evidence from European firms. NBER Working Paper Series.

Hall, B., Ziedonis, R., 2001.The patent paradox revisited: An empirical study of patenting in the U.S. semiconductor industry, 1979-1995. RAND J. Econ. 32, 101-128.

He, J., Tian, X., 2013. The dark side of analyst coverage: The case of innovation. J. Financ. Econ.109, 856-878.

Hennessy, C., Whited, T., 2007. How costly is external financing? Evidence from a structural estimation. J. of Finan. 62, 1705-45.

Hirshleifer, D., Low, A., Teoh, S., 2012. Are overconfident CEOs better innovators? J. Finan. 67, 1457-1498.

Hsu, P., Lee, H., Liu, A., Zhang, Z., 2015. Corporate innovation, default risk, and bond pricing. J. Corp. Financ. 35, 329-344.

Holmstrom, B., 1989. Agency cost and innovation. J. Econ. Behav. Org. 12, 305-327. 
Jensen, M., 1986. Agency costs of free cash flow, corporate finance, and takeovers. Am. Econ. Rev. 76, 323-329.

Jensen, M., Meckling, W., 1976. Theory of the firm: Managerial behavior, agency costs, and ownership structure. J. Financ. Econ.3, 305-360.

Jiao, Y., 2010. Stakeholder welfare and firm value. J. Bank. Finan. 34, 2549-2561.

Kamien, M.I., Schwartz, N.L., 1975. Market structure and innovation: A survey. J. Econ. Lit. 13, $1-37$.

Kaplan, S., Zingales, L., 1997. Do investment-cash flow sensitivities provide useful measures of financing constraints? Q. J. Econ. 112, 169-215.

Katila, R., Ahuja, G., 2002. Something old, something new: A longitudinal study of search behavior and new product introduction. Acad. Manag. J. 45, 1183-1194.

Kim, Y., Li, H., Li, S., 2014. Corporate social responsibility and stock price crash risk. J. Bank. Finan. 43, 1-13.

Kogan, L., Papanikolaou, D., Seru, A., Stoffman, N., 2015. Technological innovation, resource allocation, and growth. Q. J. Econ., conditionally accepted.

Landier, A., Nair, V., Wulf, J., 2009. Trade-offs in staying close: Corporate decision making and geograpihc dispersion. Rev. Financ. Stud. 22, 1119-1148.

Lamont, O., Polk, C., Saaá-Requejo, J., 2001. Financial constraints and stock returns. Rev. Financ. Stud. 14, 529-54.

Malmendier, U., Tate, G., 2008. Who makes acquisitions? CEO overconfidence and the market's reaction. J. Financ. Econ.89, 20-43.

Manso, G., 2011. Motivating innovation. J. Finan. 66, 1823-1860.

Mao, C., Weathers, J., 2015. Employee treatment and firm innovation. Working paper.

Mayer, R., Warr, R., Zhao, J., 2015. Does employee treatment and workforce diversity impact corporate innovative efficiency? Working paper.

Masulis, R., Reza, R., 2014. Agency problems of corporate philanthropy. Rev. Financ. Stud., forthcoming.

McGrath, R., 2001. Exploratory learning, innovative capacity, and managerial oversight. Acad. Manag. J. 44, 118-31.

Noel, M., Schankerman, M., 2013. Strategic patenting and software innovation. J. Ind. Econ. 61, 481-520.

Organ, D., 1997. Organizational citizenship behavior: It's construct cleanup time. Human Perform. 10, 85-97.

Sauermann, H., Cohen, W.M., 2010. What makes them tick? Employee motives and firm innovation. Manag. Sci. 56,2134-2153.

Scherer, F.M., 1965a. Corporate inventive output, profits, and growth. J. Polit. Econ. 73, 290297.

Scherer, F.M., 1965b. Firm size, market structure, opportunity, and the output of patented inventions. Am. Econ. Rev. 55, 1097-1125.

Singh, J., Fleming, L., 2010. Lone inventors as sources of breakthroughs: Myth or reality? Manag. Sci. 56, 41-56.

Trajtenberg, M., 1990. A penny for your quotes: Patent citations and the value of innovations. RAND J. Econ. 21, 172-187.

Trajtenberg, M., Henderson, R., Jaffe, A., 1997. University versus corporate patents: A window on the basicness of invention. Econ. Innov. New Tech. 5, 19-50. 
Tsai, W., 2001. Knowledge transfer in intra-organizational networks: Effects of network position and absorptive capacity on business unit innovation and performance. Acad. Manag. J. 44, 996-1004.

Tsai, W., Ghoshal, S., 1998. Social capital and value creation: The role of intra-firm networks. Acad. Manag. J. 41, 464-476.

Van de Ven, A., 1986. Central problems in the management of innovation. Manag. Sci. 32, 590607.

Verwijmeren, P., Derwall, J., 2010. Employee well-being, firm leverage, and bankruptcy risk. J. Bank. Finan. 34, 956-964.

Whited, T.M., Wu, G., 2006. Financial constraints risk. Rev. Financ. Stud. 19, 531-59. 


\begin{tabular}{|c|c|}
\hline \multicolumn{2}{|r|}{$\begin{array}{c}\text { Appendix A } \\
\text { Variable Definitions }\end{array}$} \\
\hline Panel A: Dependent variables & \\
\hline LnPat & $\begin{array}{l}\text { The natural logarithm of one plus the number of patents applied for by firm } i \text { in } \\
\text { year } t \text {. }\end{array}$ \\
\hline LnCit & $\begin{array}{l}\text { The natural logarithm of one plus the number of citations received by patents } \\
\text { applied for by firm } i \text { in year } t \text {. Raw citation count is scaled by the weights } \\
\text { proposed by Hall et al. (2001, 2005) to account for possible truncation bias } \\
\text { issues. }\end{array}$ \\
\hline LnPatVal & $\begin{array}{l}\text { Increase in market value in the three-day period of patent announcements after } \\
\text { adjusting for benchmark return, idiosyncratic stock return volatility, and } \\
\text { various fixed effect. The benchmark return is a market return, a 2-digit SIC } \\
\text { return, or a Fama-French } 48 \text { industry average return. We then sum up the value } \\
\text { of all patents filed by each firm in every year to be the value of the patent } \\
\text { generated by the firm, and take the natural logarithm of that plus one. }\end{array}$ \\
\hline Ln(ROA Growth) & $\begin{array}{l}\text { The natural logarithm of one plus the growth rate in ROA over a } 5 \text {-year period } \\
\text { from year } t \text { to year } t+5 \text {. }\end{array}$ \\
\hline Exploit & $\begin{array}{l}\text { The number of exploitative patents applied by firm } i \text { in year } t \text { divided by the } \\
\text { total number of patents applied for by firm } i \text { in year } t \text {. A patent is categorized as } \\
\text { "exploitative" if } 60 \% \text { or more of its citations reflect a firm's existing expertise, } \\
\text { which is defined as the combination of the firm's existing patents or the } \\
\text { citations made by those patents, following Benner and Tushman (2002). }\end{array}$ \\
\hline Explore & $\begin{array}{l}\text { The number of exploratory patents applied by firm } i \text { in year } t \text { divided by the } \\
\text { total number of patents applied for by firm } i \text { in year } t \text {. A patent is categorized as } \\
\text { "exploratory" if } 60 \% \text { or more of its citations do not reflect a firm's existing } \\
\text { expertise, which is defined as the combination of the firm's existing patents or } \\
\text { the citations made by those patents, following Benner and Tushman (2002). }\end{array}$ \\
\hline Depth & $\begin{array}{l}\text { The ratio of the number of repeated citations made by patents firm } i \text { applied for } \\
\text { in year } t \text { divided by the total number of citations made by all patents applied for } \\
\text { in year } t \text {. Repeated citations are citations that have been made by the firm in the } \\
\text { past five years. }\end{array}$ \\
\hline Scope & $\begin{array}{l}\text { The ratio for the number of new citations made by patents firm } i \text { applied for in } \\
\text { year } t \text { divided by the total number of citations made by all patents applied for in } \\
\text { year } t \text {. New citations are citations that have never been made by the firm in the } \\
\text { past five years. }\end{array}$ \\
\hline Generality & $\begin{array}{l}\text { The median of generality scores of all patents filed by firm } i \text { in year } t \text {. } \\
\text { Following Trajtenberg et al. (1997), we define the generality score of a patent } \\
\text { as one minus the Herfindahl index of the technology category distribution of all } \\
\text { patents that have cited this particular patent. }\end{array}$ \\
\hline Originality & $\begin{array}{l}\text { The median of originality scores of all patents filed by firm } i \text { in year } t \text {. } \\
\text { Following Trajtenberg et al. (1997), we define the originality score of a patent } \\
\text { as one minus the Herfindahl index of the technology category distribution of all } \\
\text { patents that have been cited by this particular patent. }\end{array}$ \\
\hline LnPatInv & $\begin{array}{l}\text { The natural logarithm of one plus the number of patents generated by firm } i \text { in } \\
\text { year } t \text { scaled by the total number of inventors employed by the firm. }\end{array}$ \\
\hline LnCitInv & $\begin{array}{l}\text { The natural logarithm of one plus the citation count scaled of firm } i \text { in year } t \\
\text { scaled by the total number of inventors employed by the firm. }\end{array}$ \\
\hline LnAvgTenure & $\begin{array}{l}\text { The natural logarithm of the average number of years that inventors stay with a } \\
\text { firm. This variable is calculated for each firm over the entire sample period. As } \\
\text { such, when this variable is used as a dependent variable, the regression is a pure } \\
\text { cross-sectional regression. }\end{array}$ \\
\hline LnInvPat & $\begin{array}{l}\text { The natural logarithm of one plus the average number of inventors for each } \\
\text { patent generated by firm } i \text { in year } t \text {. }\end{array}$ \\
\hline
\end{tabular}




\begin{tabular}{|c|c|}
\hline \multicolumn{2}{|c|}{ Appendix A: Variable Definitions (Cont.) } \\
\hline \multicolumn{2}{|c|}{ Panel B: Independent variables } \\
\hline Employee Treatment & $\begin{array}{l}\text { Sum of strength indicators under the employee treatment category of the KLD } \\
\text { database (divided by the total number of available categories) less the sum of } \\
\text { concern indicators under the employee treatment category of the KLD database } \\
\text { (divided by the total number of available categories). When calculating the } \\
\text { employee treatment index, we exclude categories dealing with job security (no- } \\
\text { layoff strength category) and unionization (union strength and weakness } \\
\text { category). For robustness, we also compute and use an employee treatment index } \\
\text { based on all the employee treatment dimension components. }\end{array}$ \\
\hline$R \& D /$ Assets & $\begin{array}{l}\text { R\&D expenditure scaled by total book assets. Missing R\&D values are replaced } \\
\text { with zero values. }\end{array}$ \\
\hline$R \& D$ Missing & $\begin{array}{l}\text { An indicator variable equal to one if the } R \& D \text { value is missing, and zero } \\
\text { otherwise. }\end{array}$ \\
\hline Ln(Assets) & The natural logarithm of total book value of assets. \\
\hline Ln(PPE/Assets $)$ & $\begin{array}{l}\text { The natural logarithm of property, plant, and equipment scaled by total book } \\
\text { value of assets. }\end{array}$ \\
\hline Ln(Capex/Assets) & The natural logarithm of capital expenditure scaled by total book value of assets. \\
\hline$R O A$ & Return on assets, measured as net income scaled by total book value of assets. \\
\hline Book leverage & Total debt scaled by total book value of assets. \\
\hline Sales growth & The growth rate in sales from year $t-1$ to year $t$. \\
\hline MTB & $\begin{array}{l}\text { Market book value, measured as the market value of the firm divided by the book } \\
\text { value of the firm. }\end{array}$ \\
\hline Cash holdings/Assets & Cash and short-term investment scaled by the total book value of assets. \\
\hline $\operatorname{Ln}($ Firm age $)$ & $\begin{array}{l}\text { The natural logarithm of the number of years that the firm has appeared in the } \\
\text { Compustat database. }\end{array}$ \\
\hline Competition & Herfindahl index by total sales within the firm's two-digit SIC industry peers. \\
\hline Total IO & The portion of total shares outstanding help by $13-\mathrm{F}$ institutions. \\
\hline Ln(Analysts) & The natural logarithm of the number of analysts following the firm. \\
\hline \multicolumn{2}{|l|}{ Panel C: Additional variables } \\
\hline Ln(Pension-per-employee) & $\begin{array}{l}\text { The natural logarithm of firm } i \text { 's pension expense scaled by the total number of } \\
\text { employees. The variable is measured with a five-year lag with respect to the } \\
\text { employee treatment index. }\end{array}$ \\
\hline Geographic segmentation & $\begin{array}{l}\text { The portion of firm i's value of assets held by geographic segments (as reported in } \\
\text { Compustat's Geographic segment file) divided by firm } i \text { 's total book value of } \\
\text { assets. }\end{array}$ \\
\hline Fortune 100 & $\begin{array}{l}\text { An indicator variable which identifies firms in years when they have been } \\
\text { included in Fortune's " } 100 \text { Best Companies to Work For" list. }\end{array}$ \\
\hline FCF dummy & $\begin{array}{l}\text { An indicator variable equal to one if the firm has positive free cash flow, and zero } \\
\text { otherwise. Free cash flow is defined as the sum of income before extraordinary } \\
\text { items plus depreciation and amortization less cash dividends less equity dividend } \\
\text { paid less capital expenditures or additions to fixed assets. }\end{array}$ \\
\hline$W W$ & $\begin{array}{l}\text { Financial constraint measure constructed following Whited and Wu (2006) and } \\
\text { Hennessy and Whited (2007). }\end{array}$ \\
\hline$K Z$ & $\begin{array}{l}\text { Financial constraint measure constructed following Kaplan and Zingales (1997) } \\
\text { and Lamont et al. (2001). }\end{array}$ \\
\hline$H P$ & Financial constraint measure constructed following Hadlock and Pierce (2010). \\
\hline
\end{tabular}




\section{Table 1 \\ Descriptive Statistics}

This table presents the descriptive statistics for the main variables that we use in this paper. Panel A reports descriptive statistics of dependent variables. Panel B reports descriptive statistics of independent variables. Panel $\mathrm{C}$ partitions the sample into firms with positive and negative employee treatment scores and tests the differences in means of the main innovation output across these two sub-samples. The sample period is 1992-2011.

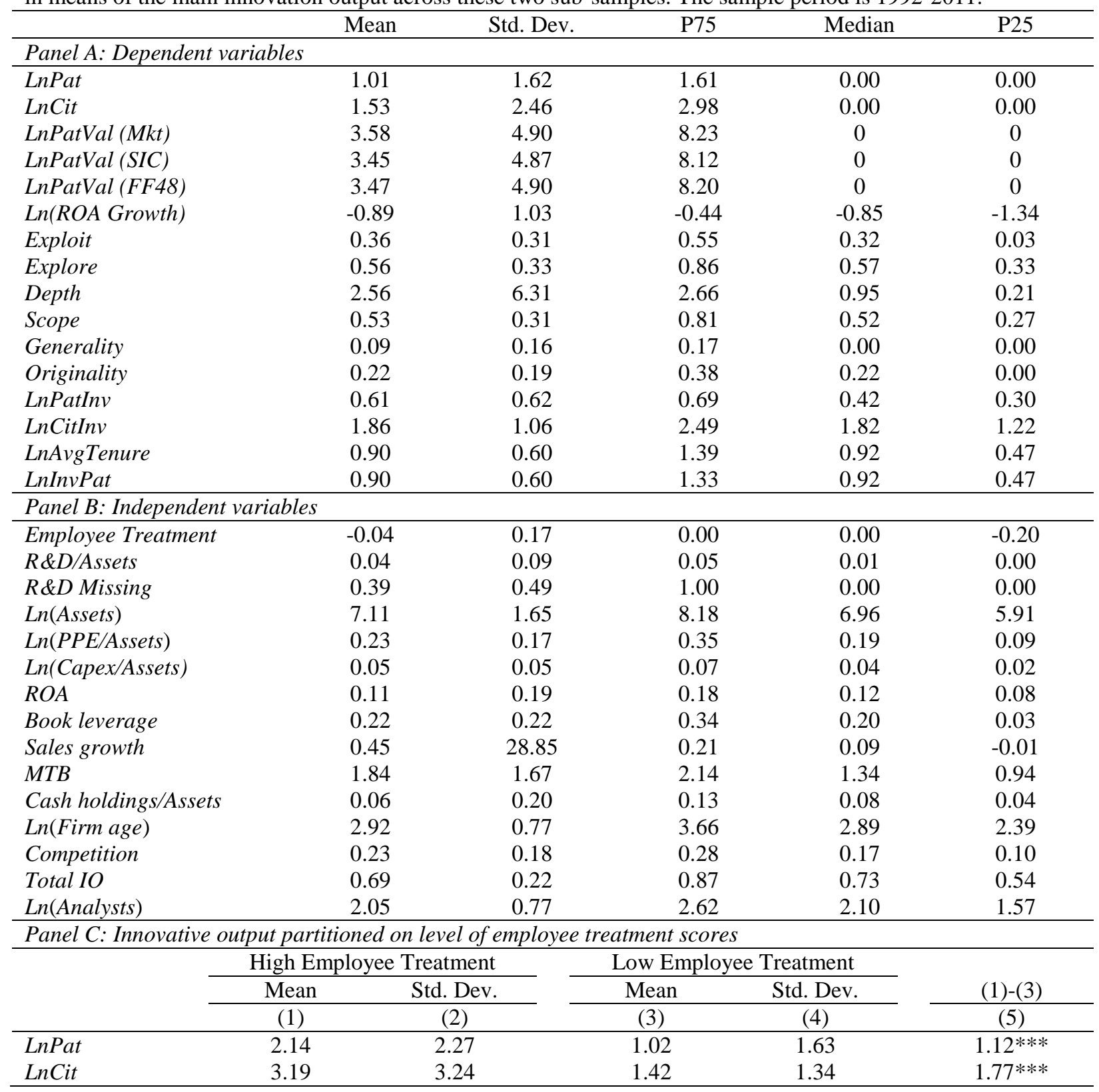




\section{Table 2}

Employee Treatment and Innovative Output - Baseline Results

This table reports results on the relation between the employee treatment index and innovative output. Employee Treatment is the main variable of interest and captures the employee treatment independent of factors involving job security and workplace unionization. LnPat is the natural logarithm of one plus patent count, while LnCit is the natural logarithm on one plus citation count. Citation count is corrected for truncation bias in line with the approach suggested by Hall et al. (2001). All independent variables are lagged by one year, relative to the dependent variables. Standard errors corrected for clustering at the firm level are reported in parentheses. *, **, *** measure significance at the $10 \%, 5 \%$, and $1 \%$ levels, respectively. Variable definitions are provided in Appendix A.

\begin{tabular}{|c|c|c|c|c|}
\hline & \multicolumn{2}{|c|}{ LnPat } & \multicolumn{2}{|c|}{ LnCit } \\
\hline & (1) & (2) & (3) & (4) \\
\hline \multirow{2}{*}{ Employee Treatment } & $0.42 * * *$ & $0.37 * * *$ & $0.50 * * *$ & $0.42 * * *$ \\
\hline & $(0.07)$ & $(0.07)$ & $(0.10)$ & $(0.09)$ \\
\hline \multirow{2}{*}{$R \& D /$ Assets } & & $2.96^{* * *}$ & & $4.16^{* * *}$ \\
\hline & & $(0.38)$ & & $(0.56)$ \\
\hline \multirow{2}{*}{$R \& D$ Missing } & & $-0.69 * * *$ & & $-1.01 * * *$ \\
\hline & & $(0.06)$ & & $(0.10)$ \\
\hline \multirow{2}{*}{ Ln(Assets $)$} & $0.41 * * *$ & $0.44 * * *$ & $0.51 * * *$ & $0.57 * * *$ \\
\hline & $(0.03)$ & $(0.03)$ & $(0.04)$ & $(0.04)$ \\
\hline \multirow{2}{*}{ Ln(PPE/Assets $)$} & $-0.89 * * *$ & $-0.52 * *$ & $-1.17 * * *$ & $-0.64 *$ \\
\hline & $(0.26)$ & $(0.23)$ & $(0.37)$ & $(0.34)$ \\
\hline \multirow{2}{*}{ Ln(Capex/Assets) } & $1.43 * * *$ & $1.39 * *$ & $1.92 * * *$ & 1.87 *** \\
\hline & $(0.44)$ & $(0.41)$ & $(0.64)$ & $(0.60)$ \\
\hline \multirow{2}{*}{$R O A$} & -0.26 & 0.17 & -0.46 & 0.14 \\
\hline & $(0.20)$ & $(0.15)$ & $(0.32)$ & $(0.23)$ \\
\hline \multirow{2}{*}{ Book leverage } & $-0.36^{* * *}$ & $-0.21 * *$ & $-0.41 * * *$ & -0.21 \\
\hline & $(0.10)$ & $(0.10)$ & $(0.14)$ & $(0.14)$ \\
\hline \multirow{2}{*}{ Sales growth } & $-0.01 * * *$ & $-0.01 * * *$ & $-0.01 * * *$ & $-0.01 * * *$ \\
\hline & $(0.00)$ & $(0.00)$ & $(0.00)$ & $(0.00)$ \\
\hline \multirow{2}{*}{$M T B$} & $0.11 * * *$ & $0.08 * * *$ & $0.17^{* * *}$ & $0.13^{* * *}$ \\
\hline & $(0.02)$ & $(0.01)$ & $(0.02)$ & $(0.02)$ \\
\hline \multirow{2}{*}{ Cash holdings/Assets } & 0.05 & $0.26 * *$ & 0.14 & $0.43 * *$ \\
\hline & $(0.12)$ & $(0.13)$ & $(0.19)$ & $(0.21)$ \\
\hline \multirow{2}{*}{ Ln(Firm age $)$} & $0.16^{* * *}$ & $0.16^{* * *}$ & $0.16^{* * *}$ & $0.16^{* * *}$ \\
\hline & $(0.04)$ & $(0.04)$ & $(0.06)$ & $(0.05)$ \\
\hline \multirow{2}{*}{ Competition } & -0.60 & -0.08 & -0.66 & 0.06 \\
\hline & $(0.48)$ & $(0.46)$ & $(0.67)$ & $(0.65)$ \\
\hline \multirow{2}{*}{ Competition $^{2}$} & 0.85 & 0.37 & 0.91 & 0.24 \\
\hline & $(0.53)$ & $(0.53)$ & $(0.73)$ & $(0.73)$ \\
\hline \multirow{2}{*}{ Total IO } & $-0.60 * * *$ & $-0.53 * * *$ & $-0.69 * * *$ & $-0.59 * * *$ \\
\hline & $(0.11)$ & $(0.10)$ & $(0.15)$ & $(0.14)$ \\
\hline \multirow{2}{*}{ Ln(Analysts) } & $0.22 * * *$ & $0.11 * * *$ & $0.31 * * *$ & $0.16^{* * *}$ \\
\hline & $(0.04)$ & $(0.04)$ & $(0.06)$ & $(0.05)$ \\
\hline Industry fixed effects & YES & YES & YES & YES \\
\hline Year fixed effects & YES & YES & YES & YES \\
\hline Observations & 16,488 & 16,488 & 16,488 & 16,488 \\
\hline $\operatorname{Adj} R^{2}$ & 0.49 & 0.54 & 0.48 & 0.52 \\
\hline
\end{tabular}




\section{Table 3}

Employee Treatment and Innovative Output - Basic Robustness

This table reports robustness test results for the baseline results reported in Table 2. Except where explicitly stated otherwise, the model employed is the same as the model used in Table 2. All the regressions include the full set of controls, as well as industry and year fixed effects. For brevity's sake, only the coefficient estimates of variables of interest are reported. Standard errors corrected for clustering at the firm level are reported in parentheses. *, **, *** measure significance at the $10 \%, 5 \%$, and $1 \%$ levels, respectively. Variable definitions are provided in Appendix A.

\begin{tabular}{|c|c|c|}
\hline & $\frac{\text { LnPat }}{(1)}$ & $\frac{\text { LnCit }}{\text { (2) }}$ \\
\hline \multicolumn{3}{|c|}{ Panel A: Use Employee treatment index incorporating all dimensions } \\
\hline Full Employee Treatment & $\begin{array}{c}0.76^{* * * *} \\
(0.13)\end{array}$ & $\begin{array}{c}0.85^{* * * *} \\
(0.17)\end{array}$ \\
\hline $\begin{array}{l}\text { Observations } \\
\text { Adj } R^{2}\end{array}$ & $\begin{array}{c}16,488 \\
0.54\end{array}$ & $\begin{array}{c}16,488 \\
0.52\end{array}$ \\
\hline \multicolumn{3}{|c|}{ Panel B: Use only strength indicators for Employee treatment index } \\
\hline Employee Treatment (Strength) & $\begin{array}{c}1.51^{* * * *} \\
(0.23)\end{array}$ & $\begin{array}{c}1.66 * * * \\
(0.31)\end{array}$ \\
\hline $\begin{array}{l}\text { Observations } \\
\text { Adj } \mathrm{R}^{2}\end{array}$ & $\begin{array}{c}16,488 \\
0.54\end{array}$ & $\begin{array}{c}16,488 \\
0.52\end{array}$ \\
\hline \multicolumn{3}{|c|}{ Panel C: Control for industry unionization } \\
\hline Industry Unionization & $\begin{array}{c}0.31 * * * \\
(0.07) \\
-0.01 \\
(0.01)\end{array}$ & $\begin{array}{c}0.35 * * * * \\
(0.10) \\
-0.01 \\
(0.01)\end{array}$ \\
\hline $\begin{array}{l}\text { Observations } \\
\text { Adj } \mathrm{R}^{2}\end{array}$ & $\begin{array}{c}12,488 \\
0.56 \\
\end{array}$ & $\begin{array}{c}12,488 \\
0.54 \\
\end{array}$ \\
\hline \multicolumn{3}{|c|}{ Panel D: Include state-year fixed effects } \\
\hline Employee Treatment & $\begin{array}{c}0.36^{* * * *} \\
(0.07)\end{array}$ & $\begin{array}{c}0.43^{* * * *} \\
(0.09)\end{array}$ \\
\hline $\begin{array}{l}\text { Observations } \\
\text { Adj } R^{2}\end{array}$ & $\begin{array}{c}16,277 \\
0.57\end{array}$ & $\begin{array}{c}16,227 \\
0.56\end{array}$ \\
\hline \multicolumn{3}{|c|}{ Panel E: Control for employee stock options } \\
\hline Employee Treatment & $\begin{array}{c}0.33 * * \\
(0.16) \\
0.09 * * \\
(0.04)\end{array}$ & $\begin{array}{c}0.46^{*} \\
(0.25) \\
0.16^{* * *} \\
(0.06)\end{array}$ \\
\hline $\begin{array}{l}\text { Observations } \\
\text { Adj R }\end{array}$ & $\begin{array}{c}2,223 \\
0.67 \\
\end{array}$ & $\begin{array}{c}2,223 \\
0.64 \\
\end{array}$ \\
\hline \multicolumn{3}{|l|}{ Panel F: Control for M\&A activity } \\
\hline Employee Treatment & $\begin{array}{c}0.36^{* * * *} \\
(0.07) \\
0.10^{* * *} \\
(0.02)\end{array}$ & $\begin{array}{c}0.41 * * * \\
(0.10) \\
0.13 * * * \\
(0.03)\end{array}$ \\
\hline $\begin{array}{l}\text { Observations } \\
\text { Adj } R^{2}\end{array}$ & $\begin{array}{c}16,488 \\
0.54\end{array}$ & $\begin{array}{c}16,488 \\
0.52\end{array}$ \\
\hline
\end{tabular}




\begin{tabular}{|c|c|c|}
\hline & LnPat & LnCit \\
\hline & $(1)$ & $(2)$ \\
\hline \multicolumn{3}{|c|}{ Panel G: Control for corporate governance } \\
\hline Employee Treatment & $\begin{array}{c}0.40^{* * * *} \\
(4.08)\end{array}$ & $\begin{array}{c}0.48^{* * *} * \\
(3.55)\end{array}$ \\
\hline E-index & $\begin{array}{c}-0.07 * * \\
(-2.52)\end{array}$ & $\begin{array}{l}-0.10^{* * *} \\
(-2.40)\end{array}$ \\
\hline Hostile index & $\begin{array}{l}-0.02 \\
(-0.06)\end{array}$ & $\begin{array}{c}0.01 \\
(0.02)\end{array}$ \\
\hline$\%$ of independent directors & $\begin{array}{c}0.93^{* * *} \\
(4.05)\end{array}$ & $\begin{array}{c}1.52 * * * \\
(4.45)\end{array}$ \\
\hline CEO duality & $\begin{array}{c}0.09 \\
(1.43)\end{array}$ & $\begin{array}{c}0.14 \\
(1.45)\end{array}$ \\
\hline $\begin{array}{l}\text { Observations } \\
\text { Adj R }{ }^{2}\end{array}$ & $\begin{array}{c}7,567 \\
0.64 \\
\end{array}$ & $\begin{array}{c}7,567 \\
0.61 \\
\end{array}$ \\
\hline \multicolumn{3}{|c|}{ Panel H: Control for CEO characteristics } \\
\hline Employee Treatment & $\begin{array}{l}0.35^{* * * *} \\
(0.11)\end{array}$ & $\begin{array}{l}0.31 * * \\
(0.14)\end{array}$ \\
\hline Holder $67 \%$ in-the-money & $\begin{array}{c}-0.22 * * * \\
(0.08)\end{array}$ & $\begin{array}{c}-0.28 * * \\
(0.12)\end{array}$ \\
\hline $\operatorname{Ln}(C E O$ age $)$ & $\begin{array}{l}-0.38 \\
(0.36)\end{array}$ & $\begin{array}{l}-0.43 \\
(0.50)\end{array}$ \\
\hline $\operatorname{Ln}(C E O$ tenure $)$ & $\begin{array}{c}0.06 \\
(0.04)\end{array}$ & $\begin{array}{c}0.08 \\
(0.08)\end{array}$ \\
\hline CEO male & $\begin{array}{l}-0.18 \\
(0.35)\end{array}$ & $\begin{array}{l}-0.01 \\
(0.41)\end{array}$ \\
\hline Observations & 6,000 & 6,000 \\
\hline Adj $R^{2}$ & 0.61 & 0.58 \\
\hline \multicolumn{3}{|c|}{ Panel I: Control for remaining KLD dimensions } \\
\hline Employee Treatment & $\begin{array}{c}0.34 * * * \\
(0.06)\end{array}$ & $\begin{array}{c}0.41 * * * \\
(0.09)\end{array}$ \\
\hline CSR score & $\begin{array}{c}0.16^{* * * *} \\
(0.06)\end{array}$ & $\begin{array}{c}0.11 \\
(0.07)\end{array}$ \\
\hline Observations & 16,488 & 16,488 \\
\hline $\operatorname{Adj} R^{2}$ & 0.54 & 0.52 \\
\hline \multicolumn{3}{|c|}{ Panel J: Control for contemporaneous innovation } \\
\hline Employee Treatment & $\begin{array}{c}0.04 * * * \\
(0.01)\end{array}$ & $\begin{array}{c}0.09^{* * * *} \\
(0.02)\end{array}$ \\
\hline Contemporaneous innovation & $\begin{array}{l}0.92 * * * \\
(0.00)\end{array}$ & $\begin{array}{c}0.81 * * * \\
(0.01)\end{array}$ \\
\hline Observations & 16,488 & 16,488 \\
\hline Adj $R^{2}$ & 0.92 & 0.85 \\
\hline \multicolumn{3}{|c|}{ Panel K: Innovation output measured at $t+2$} \\
\hline Employee Treatment & $\begin{array}{c}0.04 * * \\
(0.01)\end{array}$ & $\begin{array}{c}0.09 * * * \\
(0.03)\end{array}$ \\
\hline Contemporaneous innovation & $\begin{array}{c}0.89 * * * \\
(0.01)\end{array}$ & $\begin{array}{c}0.76^{* * * *} \\
(0.01)\end{array}$ \\
\hline Observations & 16,488 & 16,488 \\
\hline $\operatorname{Adj} R^{2}$ & 0.89 & 0.81 \\
\hline
\end{tabular}




\begin{tabular}{|c|c|c|}
\hline & LnPat & LnCit \\
\hline & $(1)$ & (2) \\
\hline \multicolumn{3}{|c|}{ Panel L: Innovation output measured at $t+3$} \\
\hline Employee Treatment & $\begin{array}{c}0.06^{* * * *} \\
(0.02)\end{array}$ & $\begin{array}{c}0.12 * * * \\
(0.04)\end{array}$ \\
\hline Contemporaneous innovation & $\begin{array}{c}0.83^{* * *} \\
(0.01)\end{array}$ & $\begin{array}{c}0.68 * * * \\
(0.01)\end{array}$ \\
\hline Observations & 16,488 & 16,488 \\
\hline $\operatorname{Adj} R^{2}$ & 0.84 & 0.75 \\
\hline \multicolumn{3}{|c|}{ Panel M: Controlling for financial constraints (measured by WW index) } \\
\hline Employee Treatment & $\begin{array}{c}0.36^{* * *} \\
(0.07)\end{array}$ & $\begin{array}{c}0.42 * * * \\
(0.09)\end{array}$ \\
\hline$W W$ & $\begin{array}{l}-0.67 \\
(0.50)\end{array}$ & $\begin{array}{l}-0.78 \\
(0.72)\end{array}$ \\
\hline Observations & 16,382 & 16,382 \\
\hline Adj $R^{2}$ & 0.54 & 0.52 \\
\hline \multicolumn{3}{|c|}{ Panel N: Controlling for financial constraints (measured by KZ index) } \\
\hline Employee Treatment & $\begin{array}{c}0.36 * * * \\
(0.07)\end{array}$ & $\begin{array}{c}0.42 * * * \\
(0.09)\end{array}$ \\
\hline$K Z$ & $\begin{array}{l}-0.01 \\
(0.01)\end{array}$ & $\begin{array}{l}-0.00 \\
(0.01)\end{array}$ \\
\hline Observations & 16,399 & 16,399 \\
\hline Adj $R^{2}$ & 0.54 & 0.52 \\
\hline \multicolumn{3}{|c|}{ Panel O: Controlling for financial constraints (measured by HP index) } \\
\hline Employee Treatment & $\begin{array}{c}0.38 * * * \\
(0.07)\end{array}$ & $\begin{array}{c}0.45^{* * * *} \\
(0.09)\end{array}$ \\
\hline$H P$ & $\begin{array}{l}-0.01 \\
(0.12)\end{array}$ & $\begin{array}{l}-0.03 \\
(0.16)\end{array}$ \\
\hline Observations & 15,471 & 15,471 \\
\hline $\operatorname{Adj} R^{2}$ & 0.54 & 0.52 \\
\hline
\end{tabular}




\section{Table 4}

\section{Employee Treatment and Innovative Output - Change Analysis}

This table reports the results on the relation between changes in employee treatment and future changes in innovative output. All variables are the first difference of the variables employed in Table 2. All independent variables are lagged by one year, relative to the dependent variables. Standard errors corrected for clustering at the firm level are reported in parentheses. *,**,*** measure significance at the $10 \%, 5 \%$, and $1 \%$ levels, respectively. Variable definitions are provided in Appendix A.

\begin{tabular}{|c|c|c|}
\hline & $\frac{\Delta L n P a t}{(1)}$ & $\frac{\Delta \ln C i t}{(2)}$ \\
\hline \multirow{2}{*}{$\triangle$ Employee Treatment } & $0.04 * *$ & $0.06^{*}$ \\
\hline & $(0.02)$ & $(0.03)$ \\
\hline \multirow{2}{*}{$\triangle R \& D /$ Assets } & 0.01 & 0.27 \\
\hline & $(0.17)$ & $(0.44)$ \\
\hline \multirow{2}{*}{$\Delta \operatorname{Ln}($ Assets $)$} & $0.08 * * *$ & $0.11 * *$ \\
\hline & $(0.02)$ & $(0.04)$ \\
\hline$\triangle L n(P P E / A s s e t s)$ & -0.03 & 0.08 \\
\hline \multirow{2}{*}{$\Delta L n$ (Capex/Assets) } & $\begin{array}{c}(0.12) \\
0.07\end{array}$ & $\begin{array}{l}(0.27) \\
0.43 *\end{array}$ \\
\hline & $(0.10)$ & $(0.26)$ \\
\hline$\triangle R O A$ & $\begin{array}{l}-0.05 \\
(0.06)\end{array}$ & $\begin{array}{c}0.02 \\
(0.16)\end{array}$ \\
\hline$\triangle$ Book leverage & $\begin{array}{c}0.01 \\
(0.04)\end{array}$ & $\begin{array}{c}0.03 \\
(0.10)\end{array}$ \\
\hline ¿Sales growth & $\begin{array}{c}0.01 \\
(0.01)\end{array}$ & $\begin{array}{l}-0.01 \\
(0.01)\end{array}$ \\
\hline$\triangle M T B$ & $\begin{array}{c}0.01 * * * \\
(0.00)\end{array}$ & $\begin{array}{c}0.01 \\
(0.01)\end{array}$ \\
\hline$\Delta$ Cash holdings/Assets & $\begin{array}{c}0.05 \\
(0.04)\end{array}$ & $\begin{array}{c}0.02 \\
(0.09)\end{array}$ \\
\hline$\Delta \operatorname{Ln}($ Firm age $)$ & $\begin{array}{c}0.05 \\
(0.06)\end{array}$ & $\begin{array}{c}0.28 * * * \\
(0.11)\end{array}$ \\
\hline$\triangle$ Competition & $\begin{array}{c}0.02 \\
(0.28)\end{array}$ & $\begin{array}{c}0.21 \\
(0.61)\end{array}$ \\
\hline$\Delta$ Competition $^{2}$ & $\begin{array}{l}-0.05 \\
(0.26)\end{array}$ & $\begin{array}{l}-0.29 \\
(0.56)\end{array}$ \\
\hline$\triangle T$ Total IO & $\begin{array}{l}-0.01 \\
(0.04)\end{array}$ & $\begin{array}{l}-0.04 \\
(0.08)\end{array}$ \\
\hline$\Delta L n($ Analysts $)$ & $\begin{array}{l}0.03^{*} \\
(0.02)\end{array}$ & $\begin{array}{c}0.00 \\
(0.03)\end{array}$ \\
\hline Industry fixed effects & YES & YES \\
\hline Year fixed effects & YES & YES \\
\hline Observations & 13,219 & 13,219 \\
\hline $\operatorname{Adj} R^{2}$ & 0.05 & 0.04 \\
\hline
\end{tabular}




\section{Table 5}

\section{Employee Treatment and Innovative Output - 2SLS Analysis}

This table reports the results on the relation between employee treatment and innovative output by using a two-stage least squares regression. The natural logarithm of geographic asset segmentation and pension expenses per employee (lagged by five years) are employed as instruments for employee treatment in the first stage. In Panel A, R\&D variables are excluded from the regression analysis, while in Panel B, R\&D variables are included in the regression analysis. All independent variables are lagged by one year, relative to the dependent variables. Bootstrapped standard errors are reported in parentheses. *, **, *** measure significance at the $10 \%, 5 \%$, and $1 \%$ levels, respectively. Variable definitions are provided in Appendix A.

\begin{tabular}{|c|c|c|c|c|c|c|}
\hline & \multicolumn{3}{|c|}{ Panel A } & \multicolumn{3}{|c|}{ Panel B } \\
\hline & \multicolumn{2}{|c|}{ Second Stage } & \multirow{2}{*}{$\begin{array}{c}\text { First Stage } \\
\text { Employee Treatment }\end{array}$} & \multicolumn{2}{|c|}{ Second Stage } & \multirow{2}{*}{$\frac{\text { First Stage }}{\text { Employee Treatment }}$} \\
\hline & LnPat & LnCit & & LnPat & LnCit & \\
\hline & (1) & $(2)$ & $(3)$ & (4) & $(5)$ & $(6)$ \\
\hline \multirow{2}{*}{ Predicted Employee Treatment } & $1.07 * * *$ & $4.39 * * *$ & & $1.14 * * *$ & $4.48 * * *$ & \\
\hline & $(0.23)$ & $(0.79)$ & & $(0.24)$ & $(0.78)$ & \\
\hline \multirow{2}{*}{$R \& D /$ Assets } & & & & $3.84 * *$ & $3.82 *$ & $0.35 * * *$ \\
\hline & & & & $(1.57)$ & $(2.05)$ & $(0.05)$ \\
\hline \multirow{2}{*}{$R \& D$ Missing } & & & & $-0.68 * * *$ & $-0.92 * * *$ & -0.02 \\
\hline & & & & $(0.17)$ & $(0.25)$ & $(0.01)$ \\
\hline \multirow{2}{*}{$\operatorname{Ln}($ Assets $)$} & $0.46 * * *$ & $0.61 * * *$ & $-0.02 * * *$ & $0.49 * * *$ & $0.65 * * *$ & $-0.01 * * *$ \\
\hline & $(0.06)$ & $(0.08)$ & $(0.00)$ & $(0.06)$ & $(0.09)$ & $(0.00)$ \\
\hline \multirow{2}{*}{ Ln(PPE/Assets $)$} & -0.69 & -0.62 & $-0.08 * * *$ & -0.35 & -0.24 & $-0.06 * *$ \\
\hline & $(0.43)$ & $(0.62)$ & $(0.03)$ & $(0.37)$ & $(0.58)$ & $(0.03)$ \\
\hline \multirow{2}{*}{ Ln(Capex/Assets) } & $1.55^{*}$ & 2.20 & $0.17 * *$ & $1.51 * *$ & $2.19 *$ & $0.16^{* *}$ \\
\hline & $(0.85)$ & $(1.52)$ & $(0.07)$ & $(0.68)$ & $(1.32)$ & $(0.07)$ \\
\hline \multirow{2}{*}{$R O A$} & $-0.50 * *$ & $-1.09 * * *$ & $0.12 * * *$ & 0.17 & -0.38 & $0.17 * * *$ \\
\hline & $(0.21)$ & $(0.40)$ & $(0.03)$ & $(0.21)$ & $(0.42)$ & $(0.03)$ \\
\hline \multirow{2}{*}{ Book leverage } & $-0.50 * * *$ & $-0.48 * *$ & $-0.03 * *$ & $-0.31 * *$ & -0.24 & -0.02 \\
\hline & $(0.15)$ & $(0.22)$ & $(0.01)$ & $(0.14)$ & $(0.18)$ & $(0.01)$ \\
\hline \multirow{2}{*}{ Sales growth } & 0.01 & 0.00 & 0.00 & -0.01 & -0.00 & -0.01 \\
\hline & $(0.03)$ & $(0.02)$ & $(0.01)$ & $(0.03)$ & $(0.02)$ & $(0.00)$ \\
\hline \multirow{2}{*}{$M T B$} & $0.14 * * *$ & $0.22 * * *$ & 0.00 & $0.09 * * *$ & $0.17 * * *$ & -0.01 \\
\hline & $(0.02)$ & $(0.03)$ & $(0.01)$ & $(0.02)$ & $(0.03)$ & $(0.01)$ \\
\hline \multirow{2}{*}{ Cash holdings/Assets } & -0.06 & 0.03 & -0.02 & $0.32 * *$ & 0.41 & 0.01 \\
\hline & $(0.14)$ & $(0.29)$ & $(0.03)$ & $(0.13)$ & $(0.28)$ & $(0.03)$ \\
\hline \multirow{2}{*}{ Ln(Firm age $)$} & $0.15 * * *$ & $0.18 *$ & -0.01 & $0.16 * * *$ & $0.20 * *$ & -0.01 \\
\hline & $(0.05)$ & $(0.11)$ & $(0.01)$ & $(0.04)$ & $(0.09)$ & $(0.01)$ \\
\hline \multirow{2}{*}{ Competition } & -0.92 & -0.58 & $-0.19 * * *$ & -0.32 & 0.06 & $-0.15 * * *$ \\
\hline & $(1.02)$ & $(1.38)$ & $(0.04)$ & $(0.85)$ & $(1.10)$ & $(0.04)$ \\
\hline \multirow{2}{*}{ Competition $^{2}$} & 1.14 & 0.71 & $0.21 * * *$ & 0.59 & 0.10 & $0.16^{* * *}$ \\
\hline & $(0.94)$ & $(1.15)$ & $(0.05)$ & $(0.80)$ & $(0.95)$ & $(0.05)$ \\
\hline
\end{tabular}




\begin{tabular}{|c|c|c|c|c|c|c|}
\hline & \multicolumn{3}{|c|}{ Panel A } & \multicolumn{3}{|c|}{ Panel B } \\
\hline & \multicolumn{2}{|c|}{ Second Stage } & \multirow{2}{*}{$\begin{array}{c}\text { First Stage } \\
\text { Employee Treatment }\end{array}$} & \multicolumn{2}{|c|}{ Second Stage } & First Stage \\
\hline & LnPat & LnCit & & LnPat & LnCit & Employee Treatment \\
\hline & $(1)$ & $(2)$ & $(3)$ & (4) & $(5)$ & $(6)$ \\
\hline Total IO & $\begin{array}{c}-0.66 * * * \\
(0.14)\end{array}$ & $\begin{array}{c}-0.81 * * * \\
(0.22)\end{array}$ & $\begin{array}{c}-0.04 * * * \\
(0.01)\end{array}$ & $\begin{array}{c}-0.63 * * * \\
(-0.13)\end{array}$ & $\begin{array}{c}-0.77 * * * \\
(0.24)\end{array}$ & $\begin{array}{c}-0.05 * * * \\
(0.01)\end{array}$ \\
\hline Ln(Analysts) & $\begin{array}{l}0.16^{* *} \\
(0.06)\end{array}$ & $\begin{array}{l}0.18 * * \\
(0.08)\end{array}$ & $\begin{array}{c}0.02 * * * \\
(0.00)\end{array}$ & $\begin{array}{c}0.06 \\
(0.06)\end{array}$ & $\begin{array}{c}0.07 \\
(0.08)\end{array}$ & $\begin{array}{l}0.03 * * * \\
(0.00)\end{array}$ \\
\hline Geographic segmentation & & & $\begin{array}{l}-0.01 * * * \\
(-0.00)\end{array}$ & & & $\begin{array}{c}-0.01 * * * \\
(0.00)\end{array}$ \\
\hline Ln(Pension-per-employee) & & & $\begin{array}{c}0.02 * * * \\
(0.00)\end{array}$ & & & $\begin{array}{c}0.02 * * * \\
(0.00)\end{array}$ \\
\hline Industry fixed effects & YES & YES & YES & YES & YES & YES \\
\hline Year fixed effects & YES & YES & YES & YES & YES & YES \\
\hline Observations & 13,059 & 13,059 & 13,059 & 13,059 & 13,059 & 13,059 \\
\hline Adj $R^{2}$ & 0.31 & 0.19 & 0.59 & 0.37 & 0.23 & 0.64 \\
\hline F-value & & & 61.21 & & & 59.81 \\
\hline Sargan test & & & 1.12 & & & 1.78 \\
\hline
\end{tabular}




\section{Table 6}

Employee Treatment and Innovative Output - Evidence from Fortune's "100" Ranking

This table reports the results on the relation between inclusion in Fortune's "100 Best Companies to Work For" list and future innovative output. In the full sample, all firm-year observations with non-missing data are included. The matched sample is constructed by matching firms which are included in the Fortune 100 list (treatment firms) to firms which are never included but have similar firm attributes as treatment firms. The probability of inclusion in the Fortune's list is measured as a function of free cash flow, cash holdings, ROA, CSR score, market-to-book value, SG\&A-per-employee expenses, as well as industry and year fixed effects. Each treatment firm is matched to its three closest control firms (for which the difference in propensity score does not exceed 1\%). All independent variables are lagged by one year with respect to the dependent variables. Standard errors corrected for clustering at the firm level are reported in parentheses. *, **, *** measure significance at the $10 \%, 5 \%$, and $1 \%$ levels, respectively. Variable definitions are provided in Appendix A.

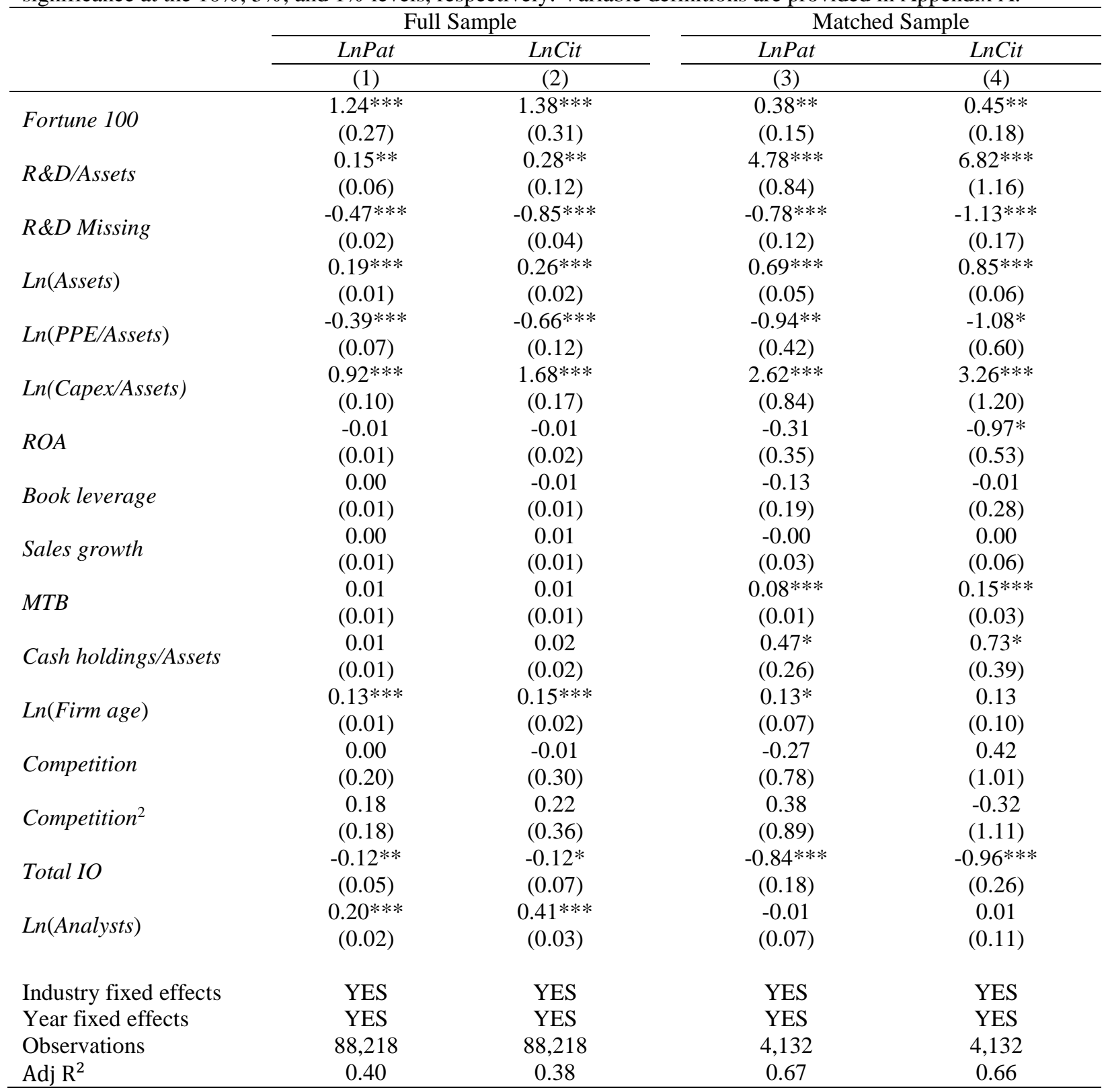




\section{Table 7}

\section{Employee Treatment and Innovative Output - Partitioning on Free Cash Flow}

This table reports the results of free cash flow's effect on the relation between employee treatment and innovative output. FCF dummy is an indicator variable equal to one for firm-years where free cash flow is positive and zero otherwise. The model is otherwise identical to the model employed in Table 2. All the regressions include the full set of controls, as well as industry and year fixed effects. For brevity's sake, only the coefficient estimates of variables of interest are reported. All independent varibales are lagged by one year with respect to the dependent variables. Standard errors corrected for clustering at the firm level are reported in parentheses. *,**, *** measure significance at the $10 \%, 5 \%$, and $1 \%$ levels, respectively. Variable definitions are provided in Appendix A.

\begin{tabular}{lccc}
\hline & LnPat & & LnCit \\
\cline { 2 - 3 } Employee Treatment & $(1)$ & $(2)$ \\
Employee Treatment $\times$ FCF dummy & $0.30^{* * *}$ & $0.34^{* * *}$ \\
& $0.09)$ & $(0.13)$ \\
FCF dummy & $(0.10)$ & 0.11 \\
& 0.01 & $(0.15)$ \\
Observations & $(0.04)$ & -0.02 \\
Adj $\mathrm{R}^{2}$ & & & $(0.05)$ \\
\hline
\end{tabular}




\section{Table 8}

\section{Employee Treatment and Patent Value}

This table reports the results on the relation between employee treatment and the value of patents generated by firms. Four measures of patent value are used. We follow Kogan et al. (2015) to calculate each patent's value as the increase in market value in the three-day period of patent announcements after adjusting for benchmark return, idiosyncratic stock return volatility, and various fixed effects. The benchmark return is a market return, a 2-digit SIC code return, or a Fama-French 48 industry average return. We then sum up the value of all patents filed by each firm in every year to be the value of a patent generated by the firm, and take the logarithm of that plus one. The model is otherwise identical to the model employed in Table 2. All independent variables are lagged by one year with respect to the dependent variables. Standard errors corrected for clustering at the firm level are reported in parentheses. $*, * *, * * *$ measure significance at the $10 \%, 5 \%$, and $1 \%$ levels, respectively. Variable definitions are provided in Appendix A.

\begin{tabular}{|c|c|c|c|}
\hline & LnPatVal (Mkt) & LnPatVal (SIC) & LnPatVal (FF48) \\
\hline & (2) & (3) & (4) \\
\hline \multirow{2}{*}{ Employee Treatment } & $0.68 * * *$ & $0.67^{* * *}$ & $0.67^{* * * *}$ \\
\hline & $(0.18)$ & $(0.19)$ & $(0.19)$ \\
\hline \multirow{2}{*}{$R \& D /$ Assets } & $8.32 * * *$ & $7.42 * * *$ & $7.54 * * *$ \\
\hline & (1.07) & (1.04) & $(1.05)$ \\
\hline \multirow{2}{*}{$R \& D$ Missing } & $-2.27 * * *$ & $-2.08 * * *$ & $-2.09 * * *$ \\
\hline & $(0.19)$ & $(0.19)$ & $(0.19)$ \\
\hline \multirow{2}{*}{ Ln(Assets) } & $1.04 * * *$ & $1.00^{* * *}$ & $1.00^{* * *}$ \\
\hline & $(0.07)$ & $(0.07)$ & $(0.07)$ \\
\hline \multirow{2}{*}{ Ln(PPE/Assets $)$} & $-1.49 * *$ & $-1.08 *$ & $-1.09 *$ \\
\hline & $(0.64)$ & $(0.66)$ & $(0.66)$ \\
\hline \multirow{2}{*}{ Ln(Capex/Assets) } & $2.67 * *$ & $2.28^{*}$ & $2.29 *$ \\
\hline & $(1.18)$ & $(1.21)$ & $(1.22)$ \\
\hline \multirow{2}{*}{$R O A$} & -0.01 & -0.21 & -0.22 \\
\hline & $(0.41)$ & $(0.42)$ & $(0.42)$ \\
\hline \multirow{2}{*}{ Book leverage } & -0.35 & $-0.97 * * *$ & $-0.98 * * *$ \\
\hline & $(0.28)$ & $(0.30)$ & $(0.30)$ \\
\hline \multirow{2}{*}{ Sales growth } & $-0.01 * * *$ & $-0.01 * * *$ & $-0.01 * * *$ \\
\hline & $(0.00)$ & $(0.00)$ & $(0.00)$ \\
\hline \multirow{2}{*}{$M T B$} & $0.25^{* * *}$ & $0.22 * * *$ & $0.21 * * *$ \\
\hline & $(0.04)$ & $(0.04)$ & $(0.04)$ \\
\hline \multirow{2}{*}{ Cash holdings/Assets } & $1.14 * * *$ & $1.48^{* * * *}$ & $1.49^{* * *}$ \\
\hline & $(0.34)$ & $(0.36)$ & $(0.36)$ \\
\hline \multirow{2}{*}{ Ln(Firm age $)$} & $0.56^{* * *}$ & $0.49 * * *$ & $0.49 * * *$ \\
\hline & $(0.10)$ & $(0.10)$ & $(0.10)$ \\
\hline \multirow{2}{*}{ Competition } & -0.80 & -1.12 & -1.15 \\
\hline & $(1.28)$ & $(1.33)$ & $(1.34)$ \\
\hline \multirow{2}{*}{ Competition $^{2}$} & 1.42 & 1.59 & 1.63 \\
\hline & $(1.50)$ & $(1.53)$ & $(1.54)$ \\
\hline \multirow{2}{*}{ Total IO } & $-1.19 * * *$ & $-1.21 * * *$ & $-1.21 * * *$ \\
\hline & $(0.26)$ & $(0.27)$ & $(0.27)$ \\
\hline \multirow{2}{*}{ Ln(Analysts) } & $0.55^{* * *}$ & $0.57 * * *$ & $0.57 * * *$ \\
\hline & $(0.10)$ & $(0.11)$ & $(0.11)$ \\
\hline Industry fixed effects & YES & YES & YES \\
\hline Year fixed effects & YES & YES & YES \\
\hline Observations & 16,488 & 16,488 & 16,488 \\
\hline $\operatorname{Adj} R^{2}$ & 0.50 & 0.48 & 0.48 \\
\hline
\end{tabular}




\section{Table 9}

\section{Employee Treatment and Effect of Innovation on Operating Performance}

This table reports the results on innovative output's effect has on future operating performance across firms partitioned on employee treatment. The dependent variable is the natural logarithm of the growth rate of ROA between year $t$ and $t+5$. Independent variables are measured at time period $t$. The High Employee Treatment subsample comprises firms which have positive employee treatment index scores, while the Low Employee Treatment sub-sample comprises firms which have negative employee treatment index scores (firms with an employee treatment index of zero are excluded from our sample). Standard errors corrected for clustering at the firm level are reported in parentheses. *,**,*** measure significance at the $10 \%, 5 \%$, and $1 \%$ levels, respectively. Variable definitions are provided in Appendix A.

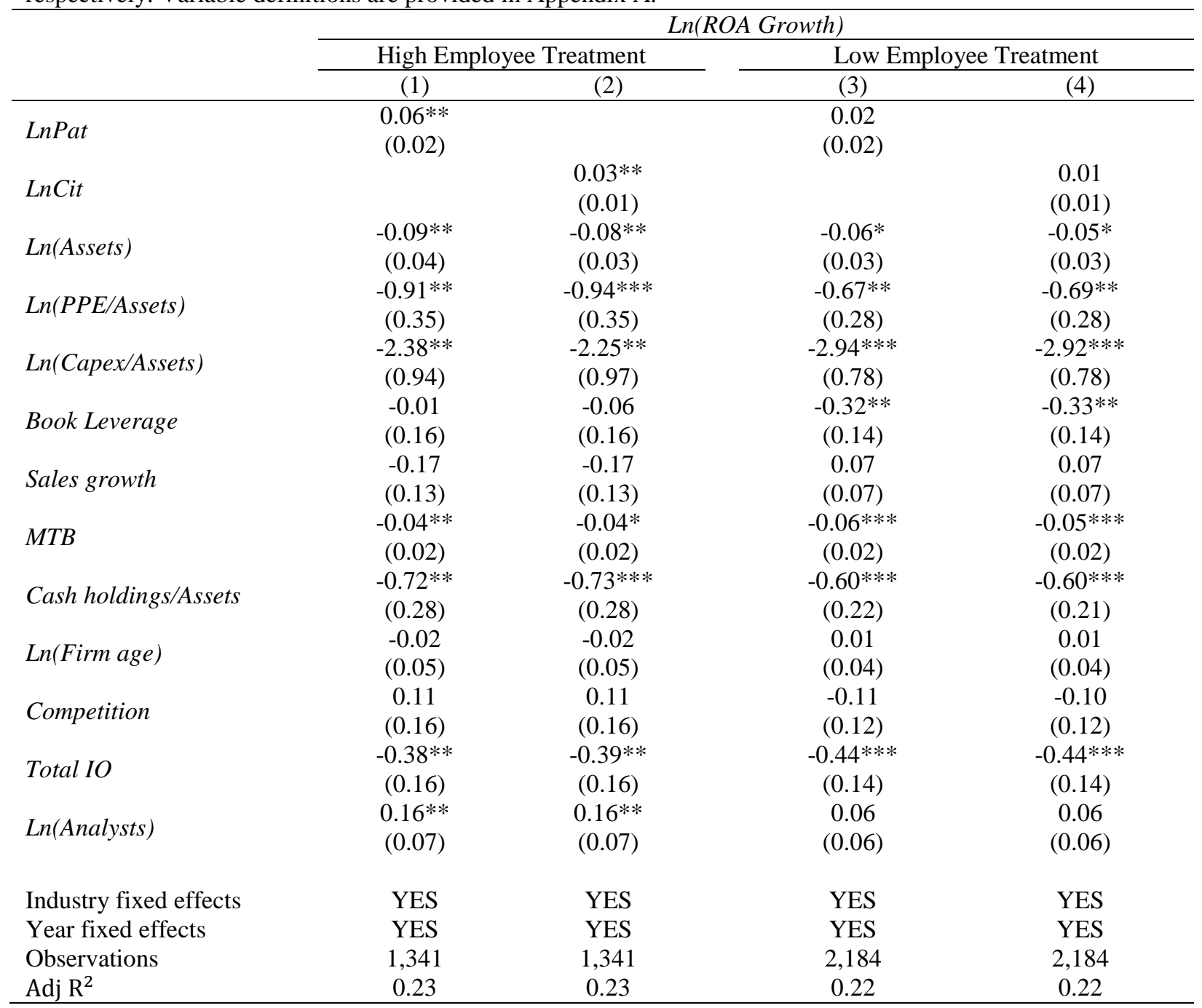


Table 10

Employee Treatment and Innovation Strategies

This table presents the regression results on the relation between employee treatment and innovation strategies pursued by firms. The definitions of exploration, exploitation, depth, scope, generality, and originality are provided in the Appendix. All independent variables are lagged by one year with respect to the dependent variables. Standard errors corrected for clustering at the firm level are reported in parentheses. *, **, *** measure significance at the $10 \%, 5 \%$, and $1 \%$ levels, respectively. Variable definitions are provided in Appendix A.

\begin{tabular}{|c|c|c|c|c|c|c|}
\hline & Exploitation & Exploration & Depth & Scope & Generality & Originality \\
\hline & (1) & (2) & (3) & (4) & (5) & (6) \\
\hline \multirow{2}{*}{ Employee Treatment } & $0.03 * *$ & $-0.04 * *$ & $0.69 *$ & $-0.04 * * *$ & $0.01 *$ & -0.01 \\
\hline & $(0.02)$ & $(0.02)$ & $(0.37)$ & $(0.02)$ & $(0.00)$ & $(0.01)$ \\
\hline \multirow{2}{*}{$R \& D /$ Assets } & 0.06 & -0.07 & 1.10 & -0.13 & $-0.11 * * *$ & $-0.16 * * *$ \\
\hline & $(0.09)$ & $(0.09)$ & (1.69) & $(0.09)$ & $(0.03)$ & $(0.05)$ \\
\hline \multirow{2}{*}{$R \& D$ Missing } & $-0.06 * * *$ & $0.08^{* * *}$ & $-1.11 * * *$ & $0.08^{* * *}$ & $0.02 * *$ & 0.01 \\
\hline & $(0.02)$ & $(0.02)$ & $(0.36)$ & $(0.02)$ & $(0.01)$ & $(0.01)$ \\
\hline \multirow{2}{*}{ Ln(Assets) } & -0.01 & -0.01 & $0.45^{* * *}$ & $-0.01 *$ & $-0.01 * * *$ & -0.00 \\
\hline & $(0.01)$ & $(0.01)$ & $(0.12)$ & $(0.00)$ & $(0.00)$ & $(0.00)$ \\
\hline \multirow{2}{*}{ Ln(PPE/Assets $)$} & -0.00 & -0.07 & -0.64 & -0.01 & 0.01 & 0.05 \\
\hline & $(0.07)$ & $(0.08)$ & $(1.91)$ & $(0.08)$ & $(0.04)$ & $(0.05)$ \\
\hline \multirow{2}{*}{ Ln(Capex/Assets) } & 0.13 & -0.10 & $8.93 * *$ & -0.22 & -0.04 & -0.05 \\
\hline & $(0.18)$ & $(0.21)$ & (3.74) & $(0.18)$ & $(0.09)$ & $(0.12)$ \\
\hline \multirow{2}{*}{$R O A$} & $-0.22 * * *$ & $0.21 * * *$ & $-2.59 *$ & $0.19^{* * *}$ & -0.02 & -0.04 \\
\hline & $(0.05)$ & $(0.06)$ & $(1.45)$ & $(0.05)$ & $(0.02)$ & $(0.03)$ \\
\hline \multirow{2}{*}{ Book leverage } & $-0.05^{*}$ & $0.05 *$ & $-1.21 * * *$ & $0.08^{* * *}$ & 0.01 & 0.01 \\
\hline & $(-0.03)$ & $(0.03)$ & $(0.46)$ & $(0.03)$ & $(0.01)$ & $(0.02)$ \\
\hline \multirow{2}{*}{ Sales growth } & $0.01 * *$ & -0.01 & -0.01 & -0.01 & 0.00 & 0.00 \\
\hline & $(0.00)$ & $(0.01)$ & $(0.01)$ & $(0.01)$ & $(0.00)$ & $(0.00)$ \\
\hline \multirow{2}{*}{$M T B$} & $0.02 * * *$ & $-0.02 * * *$ & $0.35^{* * *}$ & $-0.02 * * *$ & 0.00 & 0.01 \\
\hline & $(0.00)$ & $(0.00)$ & $(0.09)$ & $(0.00)$ & $(0.00)$ & $(0.01)$ \\
\hline \multirow{2}{*}{ Cash holdings/Assets } & $0.06^{*}$ & -0.06 & 0.24 & -0.04 & 0.01 & -0.01 \\
\hline & $(0.03)$ & $(0.03)$ & $(0.59)$ & $(0.04)$ & $(0.01)$ & $(0.02)$ \\
\hline \multirow{2}{*}{ Ln(Firm age $)$} & -0.01 & 0.01 & -0.16 & 0.01 & 0.00 & 0.01 \\
\hline & $(0.01)$ & $(0.01)$ & $(0.24)$ & $(0.01)$ & $(0.00)$ & $(0.01)$ \\
\hline \multirow{2}{*}{ Competition } & $-0.23^{* *}$ & $0.23 * *$ & $-5.28 * *$ & $0.26 * *$ & 0.04 & 0.06 \\
\hline & $(0.09)$ & $(0.11)$ & $(2.04)$ & $(0.11)$ & $(0.04)$ & $(0.06)$ \\
\hline \multirow{2}{*}{ Competition $^{2}$} & $0.19 *$ & $-0.21 *$ & $3.87 * *$ & $-0.21 *$ & -0.05 & -0.05 \\
\hline & $(0.11)$ & $(0.11)$ & $(3.82)$ & $(0.12)$ & $(0.04)$ & $(0.07)$ \\
\hline \multirow{2}{*}{ Total IO } & 0.01 & 0.01 & -0.19 & 0.00 & -0.00 & 0.03 \\
\hline & $(0.03)$ & $(0.03)$ & $(0.65)$ & $(0.03)$ & $(0.01)$ & $(0.02)$ \\
\hline \multirow{2}{*}{ Ln(Analysts) } & $0.02 * *$ & $-0.02 *$ & 0.29 & $-0.03 * *$ & $-0.02 * * *$ & $-0.04 * * *$ \\
\hline & $(0.01)$ & $(0.01)$ & $(0.19)$ & $(0.01)$ & $(0.00)$ & $(0.01)$ \\
\hline Industry fixed effects & YES & YES & YES & YES & YES & YES \\
\hline Year fixed effects & YES & YES & YES & YES & YES & YES \\
\hline Observations & 6,450 & 6,450 & 6,450 & 6,450 & 6,450 & 6,450 \\
\hline $\operatorname{Adj~} R^{2}$ & 0.16 & 0.15 & 0.24 & 0.17 & 0.25 & 0.18 \\
\hline
\end{tabular}




\section{Table 11}

Employee Treatment and Corporate Innovation - Identifying Channels

This table presents the results on the channel through which employee treatment affects innovative output. Panel A shows the relation between employee treatment and inventor efficiency. The dependent variables are the natural logarithm of innovation output (patent count or citation count) scaled by the number of inventors employed by the firm. Panel B shows the effect that employee treatment has on the length of time that inventors stay with the firm. The dependent variable in Panel B is the natural logarithm of the average tenure length of firm inventors. Panel C deals with inventor teamwork. In Panel C, we use the natural logarithm of the inventors-perpatent count to measure the teamwork. The model is otherwise identical to the model employed in Table 2. All the regressions include the full set of controls, as well as industry and year fixed effects. For brevity's sake, only the coefficient estimates of variables of interest are reported. Standard errors corrected for clustering at the firm level are reported in parentheses. $*, * *, * * *$ measure significance at the $10 \%, 5 \%$, and $1 \%$ levels, respectively. Variable definitions are provided in Appendix A.

Panel A: Inventor efficiency

\begin{tabular}{|c|c|c|}
\hline & $\frac{\text { LnPatInv }}{(1)}$ & $\frac{\operatorname{LnCitInv}}{(2)}$ \\
\hline Employee Treatment & $\begin{array}{c}0.07 * * \\
(0.03)\end{array}$ & $\begin{array}{l}0.08^{*} \\
(0.04)\end{array}$ \\
\hline $\begin{array}{l}\text { Observations } \\
\text { Adj } \mathrm{R}^{2}\end{array}$ & $\begin{array}{c}4,365 \\
0.55\end{array}$ & $\begin{array}{c}4,365 \\
0.31\end{array}$ \\
\hline \multicolumn{3}{|c|}{ Panel B: Inventor Turnover } \\
\hline \multicolumn{3}{|c|}{ LnAvgTenure } \\
\hline & \multicolumn{2}{|c|}{ (1) } \\
\hline Employee Treatment & \multicolumn{2}{|c|}{$\begin{array}{l}0.14 * * \\
(0.07)\end{array}$} \\
\hline $\begin{array}{l}\text { Observations } \\
\text { Adj } \mathrm{R}^{2}\end{array}$ & \multicolumn{2}{|c|}{1,713} \\
\hline \multicolumn{3}{|c|}{ Panel C: Inventor Teamwork } \\
\hline & \multicolumn{2}{|c|}{ LnInvPat } \\
\hline & \multicolumn{2}{|c|}{$(1)$} \\
\hline Employee Treatment & \multicolumn{2}{|c|}{$\begin{array}{l}0.04 * * \\
(0.01)\end{array}$} \\
\hline $\begin{array}{l}\text { Observations } \\
\text { Adj } R^{2}\end{array}$ & \multicolumn{2}{|c|}{16,488} \\
\hline
\end{tabular}

